\title{
Ockham, the Sanctity of Rights, and the Canonists*
}

\author{
Jonathan Robinson
}

Sixty years ago, Brian Tierney addressed the subject of William of Ockham's political thought vis-à-vis the teachings of earlier canonists. It was a subject that he has returned to several times, and Ockham has remained a focal point in many other articles and books, especially in the last few decades - too many, in fact, to list here conveniently. In that first article, the focus was on the degree to which Ockham's ecclesiological views, particularly those regarding the deposition of a heretical pope and the "location of unerring authority" in the Church, ${ }^{1}$ could be considered novel. Tied to this question was the status of Ockham's relationship to and understanding of canon law.

It is the second issue that interests me. Professor Tierney has attracted enough controversy with his publications: I do not mean to add to the list. ${ }^{2}$ One point that has not been challenged, however, was the conclusion Tierney reached regarding Ockham's

\footnotetext{
* Research for this paper was undertaken at the MGH thanks to a fellowship from the Social Sciences and Humanities Research Council of Canada. I must also thank the School of Canon Law at The Catholic University of America for their hospitality while I wrote this paper.

${ }^{1}$ Brian Tierney, 'Ockham, the Conciliar Theory, and the Canonists', Journal of the History of Ideas 15 (1954) 47.

${ }^{2}$ I refer here to his three most important books: Foundations of the Conciliar Theory: The Contribution of the Medieval Canonists from Gratian to the Great Schism (Cambridge 2010 [1955]), which was re-issued in an 'enlarged new edition' by Brill in 1998; Origins of Papal Infallibility, 1150-1350: A Study on the Concept of Infallibility, Sovereignty and Tradition in the Middle Ages (Studies in the History of Christian Thought 6; Leiden 1972); and The Idea of Natural Rights: Studies on Natural Rights, Natural Law, and Church Law 1150-1625 (Emory University Studies in Law and Religion 5; Grand Rapids 1997). The list of cranks and critics alike is again too large to include here, and, in the case of the last book, still ongoing. His most recent book, Liberty and Law: The Idea of Permissive Natural Law, 1100-1800 (Studies in Medieval and Early Modern Canon Law 12; Washington 2014), which also includes a perceptive discussion of Ockham's theory of natural law, is too new to have made any waves yet.
} 
use of the sources. Contrary to previous scholarship, ${ }^{3}$ Tierney's own extensive research into the works of the decretists and decretalists made him skeptical of Ockham's originality. ${ }^{4}$ In particular, Tierney thought that Ockham probably at least relied on Guido de Baysio's well-known compilation of earlier canonistic thought in his Rosarium (circa 1300); ${ }^{5}$ and he implied that Ockham was familiar with the Summa of the great decretist Huguccio. ${ }^{6}$ The textual evidence is certainly suggestive but hardly clinching. Partly the problem is, as Tierney said, due to the need for a critical edition of Ockham's Dialogus; but the same could be said for the Glossa ordinaria itself. Had Tierney relied on a different edition of the Gloss, there would be no need to suggest that Ockham bypassed it in favor of Huguccio's own work. ${ }^{7}$ Ultimately, the argument boils down to the fact that the Glossa ordinaria lacks the word 'romana' when it describes the Church as being wherever good people are, whereas Huguccio did make the case that wherever the good people are is where the Roman Church is. ${ }^{8}$ However, the best manuscripts of Johannes

3 See Tierney, 'Ockham, the Conciliar Theory' 41-43, for a review of earlier conclusions.

${ }^{4} \mathrm{Cf}$. the later remarks in Tierney, Origins 226.

5 Tierney, 'Ockham, the Conciliar Theory' 43, 45-46. Sometimes the implication was that Ockham had the opportunity 'to select from the works of previous expositors [i.e., canonists]' (45); cf. Brian Tierney, 'Natural Law and Canon Law in Ockham's Dialogus', Aspects of Late Medieval Government and Society. Essays Presented to J. R. Lander, ed. J. G. Rowe (Toronto 1986) 7.

${ }^{6}$ Tierney, 'Ockham, the Conciliar Theory' 60: Ockham 'neglected' much earlier decretist thought regarding nascent conciliarism, preferring instead 'to restate in detail the old arguments of Huguccio. Ockham, indeed, reproduced Huguccio's arguments more accurately than did any of the canonists whose views have been mentioned'.

${ }^{7}$ It is not clear from the article which edition he used.

${ }^{8}$ Tierney, 'Ockham, the Conciliar Theory' 64-67. Huguccio, Lons Le Saunier, Archives départementales du Jura 16 (=Jura 16) fol. 24va-24vb; Admont, SB 7 fol. ; Pembroke MS 72 fol. 130rb, to D.21 c. 3 s.v. ut [sic] rugam: 'Et est argumentum quod non [om. Jura 16] nisi boni sunt romana ecclesia; ergo ubicunque sunt boni fideles ibi est romana ecclesia. Aliter non inuenies romanam ecclesiam in qua non sint multe macule et multe ruge'. 
Teutonicus' Glossa ordinaria have 'romana ecclesia' as do the best manuscripts of the additions to Johannes' Glossa by Bartholomaeus Brixiensis. ${ }^{9}$ It is true that some printings of the Glossa ordinaria lack the word 'romana', but this is by no means universally true. In an edition from Mainz (1472), for example, the gloss does contain the phrase Ockham claimed. ${ }^{10}$

But these are mere quibbles. The fact remains that Ockham's debts to and influence on the medieval canonists requires further study. ${ }^{11}$ It has long been known that canon law served as one of his principal sources in his political writings. ${ }^{12}$ Sadly, not much

${ }^{9}$ Johannes Teutonicus, Glos. ord. to D.21 c.3 s.v. nec aliquid Admont, SB 45, fol. 27ra): 'Argumentum quod ubicumque sunt boni ibi est romana ecclesia'. The augmented Gloss by Bartholomaeus also preserved Johannes' text: Munich, BSB Clm 14005, fol. 17vb, and Munich, BSB Clm 14024 unfol.

${ }^{10}$ Cf. 1 Dial. 5.12 (fol. 39vb): 'Ubi dicit glossa ordinaria, "quod ubicumque sunt boni est Romana ecclesia”. Ex quibus uerbis datur intelligi quod tota congregatio bonorum ubicumque sunt, potest Romana ecclesia appellari; et per consequens tota congregatio fidelium potest Romana ecclesia appellari'. The draft critical edition by Kilcullen et al. has a slightly different text (though not with respect to the inclusion of 'Romana'):

see http://www.britac.ac.uk/pubs/dialogus/t1d53.html.

For abbreviations pertaining to Ockham's works, see n. 131.

${ }^{11}$ Foundations, enlarged ed. xiii-xiv. Arthur S. McGrade, The Political Thought of William of Ockham: Personal and Institutional Principles (Cambridge Studies in Medieval Life \& Thought. Third Series, 7; Cambridge 2002 [1974]) 213, who thought Ockham was often a novel interpreter of legal texts (214), repeated the call to study this aspect of Ockham's thought in the conclusion of his classic study.

${ }^{12}$ Georges de Lagarde, La naissance de l'ésprit laïque au déclin du moyen âge: 4: Guillaume d'Ockham Défense de l'Empire (5 vols. Louvain 1956-1970²) 4.51-53. The legal background and implications of the poverty controversy before Ockham has fared better. See, for instance, Paolo Grossi, 'Usus facti: La nozione di proprietà nell' inaugurazione dell'età nuova', Quaderni Fiorentini per la storia del pensiero giuridico moderno 1 (1972), 287-355 and Giovanni Tarello, 'Profili giuridici della questionedella povertà nel francescanesimo prima di Ockham', Scritti in memoria di Antonio Falchi (Milan 1964) 338-448; Andrea Bartocci, Ereditare in povertà: Le successioni a favore dei Frati Minori e la scienza giuridica nell'età avignonese (1309-1376) (Pubblicazioni del Diparti-mento di Scienze Giuridiche Università degli Studi di Roma 'La Sapienza', 32; Naples 2009), has provided a detailed legal-historical analysis for the fourteenth century. 
progress has been made on this front since Tierney concluded that where Ockham's influence on later Conciliar thought was most evident, 'he was restating, and sometimes verbally repeating, arguments which had first appeared in earlier canonistic glosses'. ${ }^{13}$ The pendulum has swung far from the view that Ockham's 'manipulation of the texts and concepts of canon and Roman law' was 'almost terrifying[ly] efficient'. ${ }^{14}$ Today the climate is much different. It is often still correctly stressed that Ockham's main sources were the Bible and canon law, ${ }^{15}$ but there is still a tendency to question how well Ockham knew his sources. ${ }^{16}$

Takashi Shogimen has recently approached the topic from another direction. While he admitted in the end that Ockham relied extensively on canon law, he framed Ockham's writings on evangelical poverty in terms of the medieval debates over the relationship of canon law and theology. ${ }^{17}$ Unlike his fellow dissident Franciscan and superior, Michael of Cesena, the heart of Ockham's defence of Franciscan poverty was grounded in theological considerations of charity. According to Shogimen,

${ }^{13}$ Tierney, 'Ockham, the Conciliar Theory' 70.

${ }^{14}$ Charles C. Bayley, 'Pivotal Concepts in the Political Philosophy of William of Ockham', Journal of the History of Ideas 10 (1949) 199.

15 E.g., Joseph Canning, Ideas of Power in the Late Middle Ages, 12961417 (Cambridge 2011) 132.

16 Janet Coleman, 'Ockham's Right Reason and the Genesis of the Political as "Absolutist",' History of Political Thought 20 (1999) 36; and restated in her A History of Political Thought: From the Middle Ages to the Renaissance (Oxford 2000) 169. Cf. the more measured view of Jürgen Miethke, 'Ockham und die Kanonisten: Ein Beispiel des Streits der Fakultäten um politiktheoretische Kompetenz im 14. Jahrhundert', ZRG Kan. Abt. 97 (2011) 399, who wrote of his increased familiarity over time.

17 Takashi Shogimen, 'The Relationship between Theology and Canon Law: Another Context of Political Thought in the Early Fourteenth Century', Journal of the History of Ideas 60 (1999) 430; see also the first chapter to his book Ockham and Political Discourse in the Late Middle Ages (Cambridge Studies in Medieval Life \& Thought. Fourth Series, 69; Cambridge 2007). Cf. de Lagarde, La naissance 4.54. There is a rich historiography on the problem of the relationship between these two spheres; Shogimen's article contains several references, especially as regards the theological 'side' of the debate (418-421). 
Ockham was not so much a good or bad expositor of legal texts as dismissive of its creators. He quoted from the concluding chapter of the fifth book of the Breviloquium (1341-1342) to illustrate his case. Ockham's discussion focused on whether Jeremias 1:10 ${ }^{18}$ indicated that the source of empire was the pope. Here Ockham was attacking a decretal of Innocent III, who had erred, argued the Franciscan, if he had used the verse (in X 1.33.6 § 3) to prove anything beyond that pontifical power is nobler than imperial power. ${ }^{19}$ Several chapters later Ockham apparently concluded that he had, stating that decretal letters are often written by various people who, being ignorant of Scripture, often include fables contrary to it, and yet who believe everything they say must be believed. $^{20}$ The magister of the Dialogus made a similar point, but made it clear that it was the 'modern' canonists who were the problem, not the authors of the sacred canons. ${ }^{21}$

What, then, are we to make of the fact that Ockham relied

18 'Ecce constitui te hodie super gentes et super regna, ut evellas, et destruas, et disperdas, et dissipes, et aedifices, et plantes'. See Yves M.-J. Congar, 'Ecce constitui te super gentes et regna (Jer. 1:10) in Geschichte und Gegenwart', Theologie in Geschichte und Gegenwart: Michael Schmaus zum 60. Geburtstag, edd. Johann Auer and Hermann Volk (Munich 1957) 671-696.

19 Brev. 5.6.25 (4:232): 'Et ideo, si Innocentius III, Extra, de maioritate et obedientia, c. Solitae [X 1.33.6] intenderet per similitudinem illam probare imperium esse a papa, erraret et sophistice procedere probaretur. Si autem intendit probare solummodo quod potestas pontificalis nobilior est quam potestas imperialis, verum probat'. See de Lagarde, La naissance 4:176-81, for the wider context.

20 Brev. 5.10.47-52 (4:245): 'Advertant igitur eruditi quanta maturitate et quibuslibet manibus saepe decretales epistolae decoquuntur, in quibus contra scripturam sacram tales fabulae inseruntur. Nec mirum, quia dictatores earum et conditor[es] saepe sunt Scripturarum ignari; qui tamen temere reputant approbandum omne, quod dicunt'. De Lagarde, La naissance 5:142-43, and n. 72, documented Ockham's criticism of the thirteenth-century pontiffs. See also Shogimen, 'Relationship' 426 for a related discussion.

211 Dial. 1.3 (2ra). See Tierney, Origins 226; Alberto Melloni, 'William of Ockham's Critique of Innocent IV', Franciscan Studies 46 (1986) 184; and John Scott, 'William of Ockham and the Lawyers Revisited', Rhetoric and Renewal in the Latin West 1100-1540: Essays in Honour of John O. Ward, edd. Constant J. Mews, C. J. Nederman, R. M. Thomson (Turnhout 2003) 169-182. Cf. also $O Q$ 1.17.206-207 (1:65). 
so extensively on legal sources for his arguments? And what can we say about Ockham as a reader of these texts? As a point of contrast, Marsilius of Padua shared Ockham's view on this score, calling the Decretales 'nothing other than certain oligarchical ordinations that the faithful of Christ are in no way bound to obey', and his works correspondingly betray very little familiarity with the texts of the Ius commune. ${ }^{22}$ In order to provide at least a partial answer to that question, I propose we look at one aspect of his political thought and compare how several canonists used similar ideas and texts in their own writings. The idea I shall examine is a very simple one, but one that played a fundamental role in Ockham's political writings. This is the idea that one's right or rights (ius or iura) should not be taken away without fault or cause - sine culpa or sine causa (henceforth, sine culpa et sine causa'). $^{23}$ It is a well-known fixture in Ockham's political writings, but, to my knowledge, no one has attempted a systematic exploration of how he applied the principle. ${ }^{24}$

I shall proceed in the following way. First, I shall examine briefly the origins of this belief in the general inviolability - or 'sanctity' - of an individual's rights; then trace how the concept was used by two of the most influential of the medieval canonists, and with whom Ockham demonstrated some limited familiarity: Pope Innocent IV (1243-1254) and Cardinal Hostiensis (†1271); ${ }^{25}$ and finally look at how Ockham deployed the same concept in his political writings. The conclusion will consider the differences between Ockham and the lawyers, and suggest that it is not so

22 Defensor pacis 2.5.5, in R. Scholz, ed. Marsilii de Padua Defensor Pacis (Fontes iuris Germanici antiqui; Hannover 1932-1933) 1:189.

${ }^{23}$ Ockham did not always use precisely the same terminology in every instance, but the principle of s.c.-s.c. is always evident.

${ }^{24}$ G. Knysh, Political Ockhamism (Winnipeg 1996) 106, was the first to draw my attention to the significance of 'sine culpa et sine causa' in Ockham's writings. Tierney, too, was well aware of how frequently Ockham repeated this notion; see Tierney, Liberty and Law 111-12, and n. 39, below.

25 In what follows, I have largely sidestepped the sizable historiography regarding these two canonists' contributions to medieval political thought. Linking studies of medieval reflection on individual rights and that body of research remains a desideratum. 
much a case of Ockham being either 'expers' or 'expertus scientiae iuristarum' as it is of a theologian constructing explicit political arguments - 'theory' might be too grandiose a term out of canon law. This differs from what the jurists were doing in two important ways: first, that they were not constructing political arguments out of legal texts as much as they were extracting and then explaining legal arguments from legal texts; and, second, even canonists did not so limit their material as to work only with the texts of canon law. Ockham's whole method of focusing almost exclusively on canon law to the exclusion of Roman law, whether born of need or choice, would have been foreign to their outlook, and inapplicable in practice.

The origin of the idea that one's 'ius' should not be taken away or interfered with arbitrarily has roots in the Corpus iuris civilis, and in Ulpian before that. The canonistic origins of this idea, however, do not seem to owe anything to Roman law. A brief examination of an important passage in the civilian tradition should help illustrate the lack of interdependence on the textual level. The text to which I refer is a quotation from a rescript regarding the mistreatment of slaves, which may not seem like the most promising place to start looking for rights. The text of the rescript, which can be found in both the Digest and Institutes, reads: ${ }^{26}$

Indeed, it is right that the power of lords over their slaves remain undiminished, and that one's right be taken away from no man. But it is in the interest of lords that assistance against cruelty, hunger, or

26 Dig. 1.6.2: 'cuius rescripti verba haec sunt: "dominorum quidem potestatem in suos servos illibatam esse oportet nec cuiquam hominum ius suum detrahi: sed dominorum interest, ne auxilium contra saevitiam vel famem vel intolerabilem iniuriam denegetur his qui iuste deprecantur. ideoque cognosce de querellis eorum, qui ex familia iulii sabini ad statuam confugerunt, et si vel durius habitos quam aequum est vel infami iniuria affectos cognoveris, veniri iube ita, ut in potestate domini non revertantur. qui si meae constitutioni fraudem fecerit, sciet me admissum severius exsecuturum".' Inst. 1.8.2 contains a more helpful preamble before providing the same quotation. The jurists who compiled King Roger II of Sicily's Constitutiones ca. 1140 used these two Roman law texts to protect the rights of slaves from mistreatment; see $\mathrm{K}$. Pennington, 'The Birth of the Ius commune: King Roger II's Legislation', RIDC 17 (2006) 23-60 at 43-47. 
intolerable injury not be denied to those who justly beg it. For this reason, be aware of the grievances of those who fled from the family of Julius Sabinus to the [imperial] statue; and if you find them kept harder than is equitable or afflicted by notorious injury, order them to be sold such that they may not be returned to the power of their lord, who, if he should break my decree, should know that I shall punish the offence more severely.

Here, perhaps, we are closer to the later history of ideas about natural subsistence rights, which might trump a lord's normal 'ius', ${ }^{27}$ or perhaps with concerns of human dignity, which are often thought to form the foundation for human rights. ${ }^{28}$ The passage did not attract much attention among the commentators. Regarding the notion that one's 'ius' should not be taken away, the Glossa ordinaria added tersely, 'unless custom introduces another [ius]'. ${ }^{29}$ Bartolus of Saxoferrato, for one, found the explanation of the gloss wanting. He added that 'by just cause' should be understood, otherwise it is simply not true, even for the prince. ${ }^{30}$

It would indeed be worthwhile to trace the arguments of

27 Scott G. Swanson, 'The Medieval Foundations of John Locke's Theory of Natural Rights: Rights of Subsistence and the Principle of Extreme Necessity', History of Political Thought 18.3 (1997), 399-459; S. G. Swanson, 'Rights of Subsistence in the Twelfth and Thirteenth Centuries: The Case of Abandoned Children and Servants', Proceedings Syracuse 1996 676-691.

28 Tony Honoré, Ulpian: Pioneer of Human Rights $\left(2^{\text {nd }}\right.$ ed. Oxford 2002) 8687. For a modern defence of dignity as a useful foundation, see Jeremy Waldron, Dignity, Rank, and Rights, ed. with an introd., by M. Dan-Cohen, in collab. with W. C. Dimock, D. Herzog, M. Rosen (The Berkeley Tanner Lectures; Oxford 2012) 13-19.

29 Accursius, Glos. ord. to Dig. 1.6 .2 (Perugia 1476) s.v. detrahi: 'nisi consuetudo aliud inducat, ut infra communia prediorum $\langle$ tam urbanorum quam rusticorum $\rangle$, Uenditor $\S$ finali [Dig. 8.4.13.1]; et facit C. de pactis 1. finali, in fine [Cod. 2.3.30.4]; et in autentico de nuptiis $\S$. Set hoc quidem [Nov. 22.26 (=Auth. 4.1) (=Sed hic quidam)]'.

${ }^{30}$ Bartolus to Dig. 1.6.1 (Milan 1490) (unfol.): 'Oppositio: dicitur hic quod ius suum non debet alicui auferri. Contra l. Si uenditor [recte: uenditor] $\S$ Si constat [Dig. 8.4.13.1], infra, communia prediorum. Solutio: quod hic dicitur est uerum "nisi consuetudo aliud inducat", quod est ualde notatum. Ex quo habetis quod consuetudo potest auferre de iure alterius quod intelligitur ex iusta causa, aliter non: quia nec princeps hoc posset, ut dixi in lege prima supra de constitutionibus principum [to Dig. 1.4.1 n. 3], quod notatur per glossam et docetur in 1. Quotiens, de precibus imperatori offerendis [Cod. 1.19.2]'. 
Bartolus here, but such an essay would lead us far from the texts Ockham claimed for his own; nor, in fact, did these ideas seem to play a role in any of the key canonistic texts that I have examined.

\section{Individual Rights in Medieval Thought?}

Currently medievalists, at least, are usually content to accept Tierney's opinion that medieval canonists played a formative role in the history of individual rights. ${ }^{31}$ Nonmedievalists are free to ignore, dismiss, or dispute this view as they wish, but let me add one reason for considering the 'iura' in this essay as being understood as individual rights by those who wrote about them. It is true that, if we take as a basic starting point that all 'ius' discussed herein is an instance of ius as it is found in Ulpian's famous description of justice as being 'the constant and perpetual will of alloting each person 'ius suum' (Dig. 1.1.10 pr.), when one considers that one's 'ius' might well be to suffer some punishment rather than to acquire some kind of right in a Hohfeldian sense, ${ }^{32}$ it becomes hard to believe we should understand this 'ius' in individual, subjective terms. But this is because we today tend to assume individual rights are essentially individual interests or benefits, ${ }^{33}$ which might float free of any

${ }^{31}$ Charles Reid, Jr, a former student of Tierney, also wrote two important, if neglected, articles on this topic; see 'The Canonistic Contribution to the Western Rights Tradition: An Historical Inquiry', Boston College Law Review 33 (1991), 37-92; 'Thirteenth-Century Canon Law and Rights: The Word ius and its Range of Subjective Meanings', Studia canonica 30 (1996), 295-342. Also useful are his 'Toward an Understanding of Medieval Universal Rights', Ave Maria Law Review 3 (2005), 95-122; 'The Rights of Self-Defense and Justified Warfare in the Writings of the Twelfth- and ThirteenthCentury Canonists', Law as Profession and Practice in Medieval Europe: Essays in Honor of James A. Brundage, eds. K. Pennington, M. H. Eichbauer (Farnham 2011) 73-91.

32 See Tierney, Idea of Natural Rights 13-42, for an enlightening discussion of this strand of historiography.

${ }^{33}$ By interests or benefits, I am trying to capture the prevalent (I think) modern viewpoint that having a right is somehow an unmitigated 'good' which we may choose to exercise or not. Cf. Ronald Dworkin, Justice for Hedgehogs (Cambridge, MA 2011) 327-328, who wrote that, 'Politicians often say that 
normative legal frameworks - despite their being understood on the model of ownership, which is often today considered the 'paradigm[atic] subjective right ${ }^{34}$ — and that they can and should be claimed against such a framework if they are not recognized. ${ }^{35}$ But the medieval view was much different in that notions of ius were often closely coupled with more or less objectively conceived normative frameworks. ${ }^{36}$ However, that does not mean that a medieval author could not conceive of 'iura' as being individually possessed and able to be exercized 'ad placitum'. That is, individual 'iura' did not exist independently of a normative body of 'ius' or law, be it natural or positive, divine or human. It may seem remarkable for people to defend the existence of human rights today and yet deny they have a basis in some kind of objective, moral 'law' but medieval authors certainly did no such thing. Natural rights are natural not only because they are 'natural' to humankind, but also because they are grounded in natural law. ${ }^{37}$ The same goes for civil rights: one can only have

people have a "right" to something - a more restrictive immigration policy, for instance - when they mean only that the public wants that policy or that, in the politicians' view, the public would be better off having it'.

${ }^{34}$ G. Samuel, 'Epistemology, Propoganda and Roman Law: Some Reflections on the History of the Subjective Right', The Journal of Legal History 10 (1989) 172; cf. H. L. A. Hart, 'Are There Any Natural Rights?' Theories of Rights, ed. J. Waldron (Oxford Readings in Philosophy; Oxford 1984) 84.

35 Ronald Dworkin, Taking Rights Seriously, with a New Appendix, [and] a Response to Critics (Cambridge 1978) xi-xiii, is a famous example of this view.

${ }^{36}$ See the interesting discussion in Kenneth Pennington, 'Lex naturalis and Ius naturale', Crossing Boundaries at Medieval Universities, ed. S. E. Young (Education and Society in the Middle Ages and Renaissance, 36; Leiden 2011) 227-253, which includes an important discussion of Aquinas lacking in an earlier version printed in The Jurist (2008). In Ockham's case, even the apparently worrisome danger of his voluntaristic tendencies (much overstated in earlier historiography) does not shake these foundations from the perspective of the human being. See Lucan Freppert, The Basis of Morality According to William Ockham (Chicago 1988) 176-79, and Arthur S. McGrade, 'Natural Law and Moral Omnipotence', The Cambridge Companion to Ockham, ed. P. V. Spade (Cambridge 1999) 273-301.

37 Richard H. Helmholz, 'Natural Human Rights: The Perspective of the Ius commune', Catholic University Law Review 52 (2003) 324. 
the civil rights civil law recognizes. ${ }^{38}$

In other words, the intuitions Ockham and the canonists had regarding these 'iura' were similar to modern concepts of rights as individually (or collectively) held benefits or claims (which might, nevertheless, entail various duties and obligations). This is clear simply because the canonists and Ockham were writing about a ius being taken away for fault or cause, with the implication being that the person in question did not want to lose the ius. An important difference between medieval and modern conceptions of rights, then, lies not in whether rights are 'subjectively' possessed, but in the medieval belief that rights were from 'ius' rather than against it. One is tempted to add that modern conceptions of rights have lost sight of this connection to 'ius', or confused it with 'lex', but that is a subject for another time. ${ }^{39}$

\section{Decretist Origins}

Medieval canon law made the point that rights should only be limited or removed due to fault or cause, or some combination thereof. $^{40}$ There are two reasons why we do not need to be so terribly surprised that medieval lawyers arrived at this legal principle. First, I suspect it was fairly uncommon - in medieval

38 It was approximately this view that motivated Bartolus of Saxoferrato's concern with tyranny. Can it be, he wondered, that the actions of some kinds of tyrants could continue to be just and binding upon their subjects? See espcially his De tyranno, questions 7 and 11, in Diego Quaglioni, ed. Politica e diritto nel Trecento italiano: Il 'De tyranno' di Bartolo da Sassoferrato (1314-1357) con l'edizione critica dei trattati 'De guelphis et gebellinis', 'De regimine civitatis'e 'De tyranno' (Il pensiero politico, Biblioteca, 11; Florence 1983) 188-196 and 205-207. See C. N. S. Woolf, Bartolus of Sassoferrato: His Position in the History of Medieval Political Thought (Cambridge 1913) 163172, and Jules Kirshner, 'Bartolo of Sassoferrato's De tyranno and Sallustio Buonguglielmi's Consilium on Niccolò Fortebracci's Tyrranny in Città di Castello', Mediaeval Studies 68 (2006) 303-312, for comment.

${ }^{39}$ See, however, Pennington, 'Lex naturalis'.

40 Brian Tierney, 'Origins of Natural Rights Language: Texts and Contexts, 1150-1250', History of Political Thought 10.4 (1989), 628, and Idea of Natural Rights 57-58, 188 n. 60, and 202, noted the canonisitic pedigree of this ideal, but did not develop it. 
Europe and elsewhere - for people (if asked) to suppose that their things could be taken away for no reason at all without their consent. Second, 'fault or cause' left unqualified, could still cover all manner of trivial justifications. ${ }^{41}$ What matters is how the principle is applied, and that is where medieval jurists excelled.

The evolution of this principle is interesting to observe. As long as the texts of the decretists remain largely unedited, the exact path cannot be reconstructed before its emergence in the Glossa ordinaria, but the following observations may be made. ${ }^{42}$ Early decretists, notably Paucapalea, Rufinus, Rolandus, Stephen of Tournai, do not seem to have made any explicit use of this principle in their commentaries. The author of the Summa parisiensis (circa late 1160's) did point in the direction of future developments in his comment to C. 16 q.7 c. 38 , a canon from the Council of Chalon-sur-Saône (813) that prohibited people from giving churches to priests or taking them away without the consent of their bishop. ${ }^{43}$ Not everyone thought that there was a lesson to be drawn here. Rolandus (circa late 1150's), for example, understood that laymen should neither appoint priests nor overturn

41 For ideas about culpability in the Ius commune, see now O. Descamps, 'L'influence du droit canonique médiéval sur la formation d'un droit de la responsabilité', Der Einfluss der Kanonistik auf die europäische Rechtskultur, vol. 1: Zivil- und Zivilprozessrecht, eds. O. Condorelli, F. Roumy, M. Schmoeckel (Norm und Struktur. Studien zum socialen Wandel in Mittelalter und Früher Neuzeit, 37.1; Vienna 2009) 137-167, esp. 146-152.

${ }^{42}$ For the biographical details of the canonists, I have relied especially on the relevant essays of W. Hartmann, K. Pennington, eds., The History of Medieval Canon Law in the Classical Period, 1140-1234: From Gratian to the Decretals of Pope Gregory IX (History of Medieval Canon Law, 6; Washington, DC 2008), and the 'Bio-Bibliographical' listing available online: http://faculty.cua.edu/pennington/biobiblio.htm.

${ }^{43}$ C.16 q.7 c.38: 'Inuentum est, quod multi arbitrii sui temeritate, et (quod est grauius) ducti cupiditate, presbiteris quibuslibet absque consensu suorum episcoporum ecclesias dant uel auferunt. Unde oportet, ut canonica regula seruata nullus absque consensu episcopi sui cuilibet presbitero ecclesiam det; quam si iuste adeptus fuerit, hanc non nisi graui culpa coram episcopo canonica seueritate amittat'. See Wilfried Hartmann, Die Synoden der Karolingerzeit im Frankenreich und in Italien (Konziliengeschichte, Darstellungen; PaderbornMünchen-Wien-Zürich 1989) 128-140. 
their appointment on their own authority. ${ }^{44}$ The Summa parisiensis, in contrast, glosses Gratian to put the stress on 'grauis culpa':45

The Summa parisiensis took as significant the point that one should not lose his church except through fault and by due process. Simon of Bisignano, a Bolognese canonist, took a similar stance in his Summa in Decretum (1177-1179). ${ }^{46}$ Commenting on a canon extracted from the letters Gregory the Great, which taught that one should lose office for one's own fault rather than the faults of another, ${ }^{47}$ Simon remarked, ${ }^{48}$

Conclude, then, that sons cannot be punished for the sins of their parents by losing a church, as below in C.1 q. 4 c.5, with the exception of simony, below in C. 1 q. 5 c. 1 and c. 2 . Hence, it is concluded from this that someone should not be deprived of his benefice of a church due to the sin of treason that his father has committed - even if sons are sometimes are made infamous by the law itself, as below, in C.6 q.1 d.p.c. 21 .

The phrase beneficium ecclesiae could be understood as a right by

${ }^{44}$ Rolandus, Summa, in F. Thaner, ed., Papst Alexander III. Summa Magistri Rolandi (Aalen 1962) 58: C.16 q.7: 'Presbyteros ab ecclesiis per laicos abiiciendos vel in eis statuendos absque voluntate episcopi Magociensi atque Cabilonensi concilio constat fore prohibitum: Laici prebyteros [C.16 q.7 c.37] etc., Inventum est [C.16 q.7 c.38] etc'.

45 Summa parisiensis, ed. T. P. McLaughlin, The Summa Parisiensis on the Decretum Gratiani (Toronto 1952) 187-188 to C.16 q.7 c.38 s.v. Inventum est: 'In hoc decreto habetur quod, si forte aliquis sacerdos seu clericus juste fuerit ecclesiam adeptus et consensu episcopi, non nisi gravi culpa et coram episcopo canonica etiam severitate eam amittere debet'.

${ }^{46}$ See Pierre V. Aimone, ed., Summa in Decretum Simonis Bisinianensis (MIC Series A: Corpus glossatorum 8; Città del Vaticano 2014) ix.

47 D.56 c.7: 'Satis peruersum et contra ecclesiasticam probatur esse censuram, ut frustra quorundam, uoluptatibus quis priuetur, quem sua culpa uel facinus ab offitiis, quo fungitur, gradu non deicit'.

48 Simon of Bisignano, Summa $49-50$ to D.56 c.7: 'Hinc collige pro peccatis parentum filios non posse puniri ecclesiam amittendo, ut infra C.i. q.iiii. Quia presulatus [C.1 q.4 c.5], excepto eo quod de simonia dicitur, infra C.i. q.v. c.i. [C.1 q.5 c.1] et ii. [c.2]. Vnde ex hoc colligitur quod non debet quis priuari beneficio ecclesie propter peccatum maiestatis quod pater commisit, etsi quandoque filii tales afficiantur ipso iure infames, ut infra C.vi. q.i. § Verum [C.6 q. 1 d.p.c. 21]'. 
medieval jurists. ${ }^{49}$ This is most easily seen in the frequent decretalist discussion about whether an individual might renounce his ius or his benefice: the terms were often interchangeable in this context. The point Simon was making was a simple one: punishment in terms of the loss of a right should occur only through one's own fault. ${ }^{50}$

As is so often the case, Huguccio sharpened the juridical principles at stake. ${ }^{51}$ Huguccio's discussion was limited, due to the nature of the material he was treating, to ecclesiastical rights. On Inuentum est, Huguccio made his point in general terms. Answering his own question about whether it mattered if a church was acquired justly or unjustly, he argued that a person should not be ejected from the church simply on the authority of the bishop or anyone else; but it does matter in terms of fault. The argument was based on the principle that 'no one ought to be deprived of his right without fault' which he drew from D.56 c.7. ${ }^{52}$ When commenting on this earlier chapter, this basic point is given a little

${ }^{49}$ E.g., Johannes Teutonicus, Glos. ord. to C. 16 q.7 c. 38 , v. 'Inuentum est', see n. 64 , below, for the text.

${ }^{50} \mathrm{Cf}$. Honorius Magistri Honorii summa 'De iure canonico tractaturus', edd. Rudolf Weigand, P. Landau, W. Kozur, in collab. with S. Haering, K. MiethanerVent, M. Petzolt (3 vols. MIC, Series A: Corpus glossatorum, 5; Città del Vaticano 2004-2010) 1.186 to D.56 c.7 s.v. Satis voluptatibus: 'idest criminibus a parentibus commisi. Hinc arg. canone tunc habito neminem debere priuari sine culpa, simile xvi. Q.vii. Inuentum [C.16 q.7 c.38], di.lxxiiii. Gesta [D.74 c.2], xxiiii. Q.iii. § i.ii [C.24 q.3 d.a.c. 1 §. 1-3]. Et hoc est regulare, nam secus contingit causaliter, ut infra contra arg. i. Q.v. c.i. [C.1 q.5 c.1] et ult. [C.1 q.5 c.3], xvi. Q.vii. Decernimus [C.16 q.7 c.32]'.

${ }^{51}$ On his life and thought, see Wolfgang P. Müller, Huguccio, the Life, Works, and Thought of a Twelfth-Century Jurist (Studies in Medieval and Early Modern Canon Law, 3; Washington, DC 1994) and his up-dated conclusions in History of Medieval Canon Law 142-160

${ }^{52}$ Huguccio, Jura 16, to C.16 q.7 c.38, v. 'Iuste' (277rb-va): 'Et nonne idem esset si iniuste? Sic quantum ad episcopum: quia non auctoritate iudicis, scilicet episcopi uel alicuius, deberet eici. Set non quantum ad culpam: quia sine omnia alia culpa eiceretur, etc. Arguitur quod nullus debet priuari iure suo sine culpa, ut di. lui, satis [D.56 c.7]'. Unfortunately, the scan I possess of Admont 7 is missing a several folios, including the page that includes this portion of his commentary. 
more precision: ${ }^{53}$

fault. [That is,] a grave one. For he is not deposed or ejected for a full, though mortal one, as in D.68 c.1. It is argued that he should not be punished, nor deprived of his own right — which he acquired canonically - for the sin of his father or that of someone else.

The point Huguccio made, then, was that legitimately acquired rights should not be taken away for the faults of others. This is unexceptional. Yet, he did not think that rights should never be taken away. His concluding remarks spell it out more clearly: 'it is normal that someone should not be deprived of his ecclesiastical right without his fault; yet, 'casualiter', it sometimes happens otherwise, as in D.22 c.6'. ${ }^{54}$ Huguccio's remarks on that chapter, in turn, suggest a large number of reasons where one might lose his right without fault. This list would become fairly standard thanks to its largely wholesale incorporation into the gloss to Priusquam (D.22 c.6). According to Huguccio, one is occasionally (quandoque) deprived of his right through no fault of his own for any of the following reasons: for favor of another thing, as D.22 c.6 itself demonstrates; due to the prerogatives of order (D.54 cc. 9,10); due to the prerogative and force of consecration (C.14 q.6 c.2); due to a strong disapproval of another (D.70 c.1; C.16 q.7 c. $32^{55}$ ); due to a fault or failing of the thing itself (C.1 q.5 c. 1 ); due to poverty or a diminished population (C.10 q.3 c.3; C.16 q.1 c.48); or due to the replacement of one person for someone more

${ }^{53}$ Huguccio, Summa Jura 16 fol. 78ra, Admont SB 7 fol. 82va-82vb,to D.56 c.7 s.v. culpa: 'culpa grauis. Nam pro ${ }^{a}$ pleni licet mortali non deponitur uel deicitur, ut di. lxviii. ${ }^{b}$ Sicut [D.68 c.1] et est argumentum quem non debeat puniri uel priuari iure proprio ${ }^{\mathrm{c}}$ quod canonice adeptus est ${ }^{\mathrm{d}}$ pro peccato patris uel alterius'. ${ }^{\text {a }}$ pro om. Admont $7^{\mathrm{b}}$ lxxiii Admont $7^{\mathrm{c}}$ proprio] primo Admont $7^{\mathrm{d}}$ est om. Admont 7

${ }^{54}$ Huguccio, Summa Jura 16 fol. $78 \mathrm{ra}$, Admont 7 fol. $82 \mathrm{vb}$ to D.56 c.7 s.v. culpa: 'est ergo regulare quem non debere priuari suo ecclesiastico iure sine sua culpa; casualiter tamen quandoque aliter contingit, ut di. xxii. ${ }^{a}$ Renouantes [D.22 c.6]'. ${ }^{a}$ xxii.] xxi. Jura 16

${ }^{55}$ For odium as 'strong disapproval', see C.16 q.7 c.32: 'Quod si spretis eisdem eisdem fundatoribus . . .' 
upright or learned. ${ }^{56}$

Huguccio's contribution to the jurisprudence of 'sine culpa et sine causa' seems to have been the following. What he made explicit was that one's rights are not normally (regulare) to be tampered with, but that there are cases (casualiter) where the normally inviolate nature of individual rights stops short. Huguccio could agree, in other words, with today's commonplace sentiment 'that no political right is absolute' ${ }^{57}$ The other point to note is that Huguccio provided a list of reasons - 'causae', in essence - for why rights might be taken away. In all but word, then, Huguccio endorsed the sine culpa and sine causa principle.

The idea caught on quickly, too. Shortly after Huguccio was writing, the maxim shows up in a decretal of Innocent III (1203; X 4.13.16). In a case where a married man became involved in an incestuous relationship with his wife's sister, one of the questions to be resolved was what to do with the wife. The ideal

${ }^{56}$ Huguccio, Summa Jura 16 fol. 26va, Admont 7 fol. 28 rb to D. 22 c. 6 s.v. prius . . . numeretur: 'Et est argumentum quod nulla culpa superueniente uel preeunte priuatur quis suo iure, et hoc fit multis de causis: scilicet propter fauorem alterius rei, ut hic factum est propter fauorem constantinopolitane ecclesie; quandoque propter prerogatiuam ordinis, ut di. liiii. Ex antiquis [D.54 c.9], Frequens [D.54 c.10]; quandoque propter prerogatiuam et uim consecrationis, ut xiiii. q.vi. Conperimus [C.14 q.6 c.2]; quandoque propter odium alterius, ut di. 1xx. Neminem [D.70 c.1] et xvi. ${ }^{a}$ q.vii. Decreuimus [C.16 q.7 c.32]; quandoque propter uitium rei habite, ut i. q.v. ${ }^{\text {c }}$ c.i. [C.1 q.5 c.1]; quandoque propter paupertatem uel defectum populi, ut X. q.iii. Vnio [C.10 q.3 c.3] et Xvi. q.i. Et temporis [C.16 q.1 c.48]; quandoque propter maiorem honestatem uel scientiam alterius, quod cotidie sit in ecclesia dei: scilicet ${ }^{\mathrm{c}}$ quis primum optinet locum, et postea alius ei preponitur qui honestate ${ }^{\mathrm{d}}$ uel scientia preminet; nec tamen ille locum suum culpa sua amittit'.

${ }^{\mathrm{a} q . v i .}$ conperimus - neminem et $\mathrm{xvi}$ om. Jura $16 \quad{ }^{\mathrm{b}} \mathrm{v}$.] vi. Jura

$16 \quad{ }^{\mathrm{c}}$ scilicet] cum $a d d$. Admont $7 \quad{ }^{\mathrm{d}}$ honestate] honeste Jura 16

${ }^{57}$ Dworkin, Justice for Hedgehogs 373. Alan Gewirth, 'Are There Any Absolute Rights?', Theories of Rights, ed. Jeremy Waldron (Oxford Readings in Philosophy; Oxford 1984) 91-109, provided a robust analysis of what is at stake for would-be absolute rights. See John Finnis, Natural Law and Natural Rights (Clarendon Law Series; Oxford 20112) 223-226, 455-456, 467, for a discussion of the role of absolute natural rights. 
solution would be for her to remain chaste while her husband remained alive, but Innocent conceded that this might prove too difficult. In this case, the husband was bound to pay the debitum coniugale: because the wife was not a iniquitatis particeps, she should not be deprived of her right. Innocent added a significant considerandum; the text reads: ${ }^{58}$

Hence, she should not be deprived of her right without her own fault, even though it is said by some of our predecessors in a similar case that there was a distinction whether in fact the adultery or incest was manifest or hidden, with others asserting instead that one must distinguish between a proximate and remote grade [of consanguinity].

Is this concession an indication that earlier pontiffs were less concerned about depriving people of their rights without fault? It is certainly a topic worth of further investigation, especially given the full use of the concept in the Glossa ordinaria just a few decades later. ${ }^{59}$

Let me note in conclusion one related avenue of study, namely the distinctly canonistic 'ius ad rem', a term coined to capture the 'aliquid iuris' - to use Innocent III's phrase (3 Comp. 3.30.4 [= X 3.38.29]) — that one seems to acquire through presentation by a lay patron. Peter Landau has already written an excellent article on the early history of this term, but I wish to note a significant discussion by the canonist Tancred. In his Apparatus to 3 Comp. 1.19.4, he reviewed the problems associated with lay presentation. Tancred denied that a person so presented gained any 'ius in re' (scilicet in ecclesia), limiting what is acquired to a 'ius

${ }^{58}$ Innocent III, Die Register Innocenz' III, vol. 6: Pontifikatsjahr, 1203/1204, Texte und Indices, eds. O. Hageneder, J. C. Moore, A. Sommerlechner, in collab. with C. Egger, H. Weigl (Publikationen des Historischen Instituts beim Österreichischen Kulturinstitut in Rom; Vienna 1995), no. 5 (5-6): 'Unde iure suo sine sua non debet culpa privari, quamquam a quodam predecessorum nostrorum dicatur in simili casu fuisse distinctum, utrum videlicet adulterium vel incestus manifestum fuerit vel occultum; aliis asserentibus inter gradum proximum et remotum esse potius distinguendum'. I wish to thank Ken Pennington for drawing my attention to this passage.

${ }^{59}$ The pertinent gloss in this case, v. 'sine culpa' only refers the reader to the fuller discussion on X 4.13.11: 'Hoc generale est. Simile, eodem, c. ult.; si qua contraria sunt casualia sunt'. See the discussion in $\mathrm{n}$. 71 and accompanying text below. 
sibi ad rem ipsam, scilicet petendam, ut confirmetur'. So far, this is unsurprising, but his rationale is of interest to us. The reason he has a right to seek confirmation 'contra episcopum', he explained, was because the bishop had repelled him 'sine causa'. ${ }^{60}$ Clearly the 'ius ad rem petendam' in this formulation will remind one of Celsus' definition of 'actio', that is, 'nothing other than a right to seek in court what one is due', ${ }^{61}$ but there is ample evidence that the decretalists denied such was the case. ${ }^{62}$ What is significant, though, is that the 'ius' in Tancred's view arises due to a 'sine causa' exclusion. As Tancred composed his Apparatus around the same time (circa 1216-1220) that Johannes Teutonicus was working on what would become the Ordinary Gloss, and who held a very similar position, ${ }^{63}$ it is clear that the decades around the turn of the century clearly deserve far greater scrutiny for understanding the origins and evolution of 'sine culpa et sine causa'.

\section{The Texts in the Glossa Ordinaria}

Of the four glosses that incorporate the 'sine culpa et sine causa' principle, two are found in Glossa ordinaria to the

603 Comp. 1.19.4 s.v. 'Cum igitur plus iuris habeat', ed. F. Gillmann, 'Zum Problem vom Ursprung des ius ad rem', AKKR 113 (1933) 483-484: 'quia licet ex presentatione laici patroni non acquiritur ius presentato in re ipsa, acquiritur ius sibi ad rem ipsam, scilicet petendam, ut confirmetur, et contra episcopum, qui eum sine causa repellit, ut in decretali Pastoralis [3 Comp. 3.30.4 $(=\mathrm{X}$ 3.38.29)]. t.' See Peter Landau, 'Zum Ursprung des 'Ius ad rem' in der Kanonistik', Proceedings Strasbourg 1968 81-102 89-92 and 97-98, for discussion of Pastoralis and Tancred's gloss.

61 Dig. 44.7.51 (1:768): 'Nihil aliud est actio quam ius quod sibi debeatur, iudicio persequendi'. Cf. Inst. 4.6 pr. (1:47).

62 See especially Harry Dondorp, 'Zum Begriff Ius ad rem bei Innocenz IV', Proceedings Munich 1992 555-559.

${ }^{63}$ Johannes Teutonicus to 3 Comp. 1.4.3, v. 'tanta divisione', K. Pennington ed., Johannis Teutonici Apparatus glossarum (MIC, Series A: Corpus glossatorum, 3; Vatican City 1981) 36: 'item et indirecte cogitur dare postulatum quia si eum repellat sine causa, providebit ei alias, ut infra de iure patronatus, Pastoralis [3 Comp. 3.30.4 (=X 3.38.29)]'. See also Dondorp, 'Zum Begriff Ius ad rem' 555. 
Decretum, ${ }^{64}$ while two others are found among the glosses to the Liber extra. A closely related idea was eventually codified in the Liber sextus as one of the Regulae iuris, which stated that one should not be punished without fault, unless there is an underlying cause. ${ }^{65}$ Ockham referred on occasion to all but one of these passages. The first, Priusquam (D.22 c.6), makes explicit Huguccio's point that although neither a person's nor a church's right or privilege is taken away without fault - such as excessive damages, abuse of authority, ${ }^{66}$ delict, negligence, or inaction (contrarium factum $)^{67}$ - it may well be if there is cause. The causes it mentions will largely be familiar to readers of Huguccio: favor or disapproval, the force of consecration, scandal, a failure to attain the priesthood (defectum sacramenti), poverty, clerical order (ordines). ${ }^{68}$

${ }^{64}$ See also Johannes Teutonicus, Glos. ord. to C.16 q.7 c. 38 s.v. Inuentum est: 'Item arguitur quod nullus debet priuari suo beneficio sine culpa sua, ut lvi. di. Satis peruersum [D.56 c.7] et extra. de constitutionibus, Cognoscentes [X 1.2.2]; arguitur contra de clerico egrotante c. ultimo [X 3.6.6]. Set illud propter scandalum, pro quo multa omittuntur, ut di. 1. Vt constituerentur [D.50 c.25], extra de noui operis nunciatione, Cum ex iniuncto [X 5.32.2]'. The text has changed from Huguccio's 'ius' to 'beneficium', though the latter was treated as the proper object of a 'ius', if not a 'ius' itself.

${ }^{65}$ VI 5.13, Regula iuris, 23: 'Sine culpa, nisi subsit causa, non est aliquis puniendus'. The Glossa ordinaria sums up the received wisdom of the earlier glosses; see Johannes Andreae, Glos. ord. to VI 5.13 reg. 23 s.v. sine culpa, see also X 2.6.5 § 4: ‘. . . in quibus coniuges sine culpa, set non sine causa continere coguntur'; this passage was often cited as proof that a 'causa' subsists where no fault is present. Ockham made no explicit use of this decretal.

${ }^{66}$ C.11 q.3 c.63: '. . . qui permissa sibi abutitur potestate'.

${ }^{67}$ See Bernardus Parmensis, Glos. ord. to X 5.33.6 s.v. tempore: the passage to which the gloss refers, which explains that a privilege is lost if one does not make use of it.

${ }^{68}$ Johannes Teutonicus, Glos. ord. to D.22 c.6 s.v. Priusquam: 'Sic ergo aliqua ecclesia priuatur iure suo sine culpa sua, et hoc fit quandoque propter fauorem, quandoque odium. Propter fauorem multipliciter. Uno modo ut hic. Alio modo fauore sacerdotii, ut liv. di. Frequens [D.54 c.10]. Et alio modo propter uim consecrationis, ut xiv. q.vi. Conperimus [C.14 q.6 c.2]. Quandoque propter fauorem religionis, ut extra, de ecclesiis edificandis, Ad audientiam 2 [X 3.48.5]. Quandoque propter scandalum, ut extra. de clerico egrotante Tua [X 3.6.4]. Quandoque propter defectum sacramenti, ut xxxiv. di. Si cuius [D.34 c.11]. Item propter odium alterius, ut lxx. di. Neminem [D.70 c.1]; xvi. 
The second, Perversum, which Ockham either did not know or simply never cited, again emphasized that rights may be taken away without a serious fault (grauissimo delicto), but not without cause; the point is repeated about punishment. ${ }^{69}$ In the Decretales, the essence of earlier teaching was distilled. Rights are not normally (regulariter) taken away without fault, but they may be taken away by cause. And the list of causes was narrowed to a handy, if badly versified list of six: poverty, strong disapproval, vice, favor, crime, and (clerical) order. ${ }^{70}$ The second gloss in the

q.vii. Decernimus [C.16 q.7 c.32]. Propter paupertatem, x. q.iii. c. Vnio [C.10 q.3 c.3]. Item propter ordines, ut dicto Frequens [D.54 c.10]. Alias regulare est, quod nemo sine culpa sua priuandus est iure suo, ut xvi. q.vii. Inuentum [C.16 q.7 c.38], et lvi. di. Satis peruersum [D.56 c.7]. Hic potest habere locum distinctio, quod quandoque perditur priuilegium propter fauorem, ut hic. Quandoque propter enorme damnum, ut extra. de decimis, Suggestum [X 3.30.9]. Quandoque propter abusum, ut xi. q.iii. Priuilegium [C.11 q.3 c.63]. Quandoque propter delictum, xxv. q.ii. Ita nos [C.25 q.2 c.25]. Quandoque propter negligentiam, ut ff. de Nundinis, 1.1 [Dig. 50.11.1]. Quandoque propter contrarium factum, extra. de priuilegiis, $\mathrm{Si}$ de terra [X 5.33.6], et c. Accedentibus [X 5.33.15]. Et nota quod licet quis sine culpa perdat priuilegium, numquam tamen sine causa, ut extra, ut lite non contestata 〈non procedatur ad testium receptionem uel ad sententiam diffinitiuam $\rangle$, quoniam frequenter [X 2.6.5]'.

${ }^{69}$ Johannes Teutonicus, Glos. ord. to D.56 c.7 s.v. Satis perversum: 'Istud capitulum intelligitur de iam promoto; talis enim propter delictum alterius non priuatur iure suo. Non est enim priuandus quis iure suo nisi pro grauissimo delicto, ut xvi. q.vii. Inuentum [C.16 q.7 c.38] et lxxiv. di. Gesta [D.74 c.2]. Excipiunt quidam casum in eo qui ignoranter est adeptus beneficium pecunia patris: ut i. q.v. c.i. Set illud ideo perdit quia furtiuum est. Set quid si pater commisit crimen lese maistatis? Nonne filius priuandus est beneficio cum sit infamis factus, ut vi. q.i. § Si quis cum [C.6 q.1 c.22]; et infames promoti etiam deiiciuntur; ut vi. q.i. Infames? [C.6 q.1 c.17]. Non: quia cum sit clericus est exemptus a iurisdictione principis. vic. di. Duo [D.96 c.10]; i. q.iv. § Contra in fine [C.1 q.4 d.p.c.9]. Item fallit illud, extra. de ecclesiis edificandis, Ad audientiam ii. [X 3.48.5]; et extra. de clerico egrotante c.ii. [X 3.6.2]: ubi quis sine culpa priuatur iure suo. Hoc tamen scias quod multotiens punitur quis sine culpa sua, set non sine causa, ut extra. ut lite non contestata, Quoniam [X 2.6.5]; supra, xxxiv. di. Si cuius uxorem [D.34 c.11]'.

${ }^{70}$ Bernardus Parmensis, Glos. ord. to X 1.2.2 s.v. culpa: 'Quia quod legitime factum est penam non meretur, C. de adulteriis, Gracchus [Cod. 9.9.4pr.]; et peccata suos debent tenere auctores, C. de penis 1. Sancimus [Cod. 9.47.22]; 
Decretales is the most succinct. Simply put, rights should not be removed 'sine culpa'; but in the counter-counter-example (namely, D.22 c.6), it is noted that people may be punished sine culpa where there is an underlying cause. ${ }^{71}$

It is clear that the Glossa ordinaria defended the view that rights were normally to be safe-guarded, not ignored or taken away in the normal course of events. ${ }^{72}$ It would be interesting to trace how this doctrine was received by the leading canonists, and indeed the civilians as well as medieval theologians, but I cannot provide such a total history here. Instead, I shall confine myself to a consideration of the writings of Pope Innocent IV and Cardinal Hostiensis.

\section{Pope Innocent IV}

Among the decretalists, few can match Sinibaldo dei

et infra de his que fiunt, Quesiuit [X 3.11.2]; et infra de sententia excommunicationis, Romana, in fine [VI 5.11.5]. Et ita est hic argumentum expressum quod nemo priuatur iure suo sine culpa, lvi. di. Satis peruersum [D.56 c.7]; xvi/ q. ulti. Inuentum [C.16 q.7 c.38]; de restitutione spoliatorum, Conquerente [X 2.13.7]. Argumentum contra: xxii. di. Renouantes [D.22 c.6]; et xxxiv. di. Si cuius uxorem [D.34 c.11] et c. sequenti [D.34 c.12]; et xxvii. q.ii. Multorum [C.27 q.2 c.20]; infra de clericis coniugatis, Sane [X 3.3.2]. Solutio: prima rubrica regulariter uera est, contraria casualia sunt; uel dicas quod licet quandoque quis priuetur iure suo sine culpa: non tamen fit istud sine causa: infra ut lite non contestata, Quoniam frequenter $\S$ Si uero [X 2.6.5 §. 2] Et causam facile est uidere in contrariis signatis. In vi. casibus priuatur aliquis iure suo sine culpa sua. Unde uersus:

Paupertas, odium, uitium, fauor et scelus,

Ordo personas spoliant et loca iure suo.

Ista notantur in c. Renouantes [D.22 c.6]; et infra de priuilegiis, Antiqua [X 5.33.23], ubi de hoc'.

${ }^{71}$ Bernardus Parmensis, Glos. ord. to X 4.13.11 s.v. sine propria culpa: 'Nullus sine culpa sua iure suo debet priuari, similiter supra, eodem, Discretionem [X 4.13.6]; lvi. di. Satis peruersum [D.56 c.7]; xvi. q.ultima Inuentum [C.16 q.7 c.38]. Argu-mentum contra: supra ut lite non contestata, Quoniam frequenter $\S$ $\mathrm{Si}$ in fine [ uero [X $2.6 .5 \S 2$, i.e. $\S 4]$; et infra, de priuilegiis $\langle$ et excessibus priuilegiatorum $\rangle$, antiqua [X 5.33.23]. Contra: 22 di., renouantes [D.22 c.6]. Set ibi causa subest quare puniuntur sine culpa'.

${ }^{72} \mathrm{Cf}$. X 3.36.2: 'Nam sic huius loci ordinationem disponimus, ut tamen iura sua singulis episcopis inviolata servemus'. The point is repeated in the gloss s.v. cuius est diocesis. See also the texts cited on n. 114, below. 
Fieschi, later Pope Innocent IV, for his influence on later jurisprudence. ${ }^{73}$ For Innocent, our problem is that he did not provide much insightful discussion on either of the two decretals of the Liber extra. The comment to Iordanae (X 4.13.11), for instance, is empty. We only have slightly more in Cognoscentes, where Innocent explained that the sine culpa principle fails in some cases, or where a cause is present. ${ }^{74}$ In other words, Innocent adhered to the consensus view, citing several of the same references as the Gloss.

Yet Innocent was hardly unconcerned with rights. His commentary betrays a keen interest in the rights and right order for churches and churchmen alike. ${ }^{75}$ One of Innocent's concerns was whether it was even possible for one to possess a 'ius' ${ }^{76}$ The discussion is most pronounced in the titles dealing with possession and ownership (X 2.12) and the restitution of spoils (X 2.13). Given the subject matter one might think Innocent would discuss standard matters of property ownership, but this is not the case. The rights Innocent listed as possible candidates for being possessed in his commentary to Susceptis (X 2.12.1) were 'iura episcopalia', 'ius eligendi', and 'ius iudicandi', along with a 'ius seruitutis'. Initially drawing on classical Roman law ideas, Innocent started his comments by noting that such 'iura' are not, properly speaking possessed, nor even 'quasi possessed' ${ }^{77}$ What

\footnotetext{
${ }^{73}$ See Alberto Melloni, 'Sinibaldo Fieschi (Innocenzo IV, papa)', DGI 2.18721874.

${ }^{74}$ Innocent IV, Commentaria (Frankfurt am Main 1570) fol. 2va to X 1.2.2 s.v. culpa:: 'Fallit in casibus: 22 di. Renouantes [D.22 c.6]; 27 q.2 Qui multorum [C.27 q.2 c.20]; infra, de clericis coniugatis, Sane [X 3.3.2]. Uel etiam ibi causa suberat et sine culpa, infra, ut lite non contestata, Quoniam frequenter [X 2.6.5]'.

${ }^{75}$ John A. Kemp, 'A New Concept of the Christian Commonwealth in Innocent IV', Proceedings Boston $1963155-159$ at 157.

${ }^{76}$ See Dondorp, 'Zum Begriff Ius ad rem' 562-565, for a parallel discussion.

${ }^{77}$ Innocent IV op. cit. fol. 219 va to X 2.12 .1 s.v. momenti: 'id est, possessionis que parata est per momentum durare. Nota quod iura proprie non dicuntur possideri, nec quasi possideri, nec ab his qui ea in ueritate habent, puta, ut iura episcopalia, uel huiusmodi, uel ius seruitutis, uel huiusmodi. Quod sic probo, quia non sunt, nec quasi possideri possunt ab his, qui ea non habent'.
} 
actually mattered, he went on to explain in an allusion to a Roman law perspective, was the actual exercise (exercitium or usus) of the 'iura'. ${ }^{78}$ But even this answer proved somewhat unsatisfactory, and he concluded his comment with the following consideration: ${ }^{79}$

Some say, and perhaps better, that it is more properly said that someone is 'in possession' of a right of electing, or of advancing (eundi), than that someone is 'in possession of exercising' these rights; for one can well have possession of some right though he may not 'have' that right: because, although he himself may not have [it], another nevertheless does have [it]; or even if no one has [it], it still exists in reality, either in act or in habit.

Innocent seems to have thought the benefits of using, a more easily understood way of speaking, outweighed the value of sticking to the terminology of the classical jurists, who preferred to speak about 'usus iuris' than the possession of 'ius' ${ }^{80}$ This view can also be seen where he wrote that possession of 'iura' is acquired in much the same way as corporeal things are insofar as it remains a question of 'animus' and 'corpus'. In fact, some rights are acquired through the introduction of a corporeal thing. For example, if someone wants to give the possession of tithes, what would be given is a tithal estate (fundum decimale). Regarding other incorporeal rights, however, such as the 'ius canonicum', possession is said to be acquired generally: for example, if someone be given a place in the church choir (stallum in choro). ${ }^{81}$

If it was difficult for Innocent to specify the mechanisms of acquisition without analogy to how 'possessio' worked for corporeal things, he found it easier to argue that they should not

${ }^{78}$ See A. Berger, 'Encyclopedic Dictionary of Roman Law', Transactions of the American Philosophical Society 43(1953), 333-809, v. 'Possessio iuris' (637) and 'usus iuris' (755).

${ }^{79}$ Innocent IV ed. cit. fol. 219va-219vb to X 2.12.1: 'Alii dicunt et forte melius, quod proprius dicitur, quod aliquis est in possessione iuris eligendi, uel eundi, quam quod aliquis est in possessione exercendi hec iura; bene enim quis potest habere possessionem alicuius iuris, licet ipse non habeat illud ius, quia licet ipse non habeat, alius tamen habet, uel etiam si nullus habet, est tamen in re, uel actu, uel habitu'.

${ }^{80} \mathrm{Cf}$. Innocent IV ed. cit. fol. 388rb to X 3.14 .4 s.v. ad ius ecclesie, where he defended the claim that both 'possessio' and 'proprietas' could be said to be alienated 'in larga significatione'.

${ }^{81}$ Ibid. fol. $227 \mathrm{va}-227 \mathrm{vb}$ to X 2.13.5 n. 6 . 
be interfered with arbitrarily. In a decretal which defends religious houses from lay interference (X 3.49.1), Innocent posed a hypothetical question, which he then answered: ${ }^{82}$

But what if he be denied hospitality? Can he enter the house under his own authority, and receive necessities for hospitality - even violently - since he has the right of receiving this and since he is also in quasi possession? It seems that it is so because everyone is allowed to defend his right and possession, and to repel force with force: Cod. 8.4.1; above, X 2.13.12.

But it is not that simple. After noting that all these goods are the holy things of the saints and consecrated to the Lord, Innocent turned the tables. Such a person cannot violently take necessities for hospice or violently enter the house because no religious house owes such servitude. His conclusion was that a bishop or someone else who has jurisdiction over some church can break into the house and violently expel a person who entered that church iniquitously, even though he may have jurisdiction as well. ${ }^{83}$

In terms of the actual deprivation of rights, Innocent did not make explicit use of the 'sine culpa' principle, but he did discuss the loss of rights 'ex causa'. At one point, he suggested that the exspoliation of incorporeal rights requires deceit (dolus), just as it does for the exspoliation of corporeal things. ${ }^{84}$ In another comment he argued that legal possession should not be taken away without investigation of the case (causa). ${ }^{85}$ Perhaps the most significant usage of an 'ex causa' loss of rights is when he

\footnotetext{
${ }^{82}$ Ibid. fol. $458 v b$ to $X$ 3.49.1 n. 2: 'Set quid si negaretur hospitium? Potestne sua authoritate intrare domum, et necessaria in hospitio recipere, etiam uiolenter, cum ius habeat hoc recipiendi, et etiam sit in quasi possessione? Uidetur quod sic: quia licet cuique ius suum et possessionem defendere, et uim ui repellere: C. unde ui 1. 1 [Cod. 8.4.1]; supra, de restitutione spoliatorum, olim [X 2.13.12]'.

${ }^{83}$ Ibid. fol. $458 \mathrm{vb}-459$ ra to $X$ 3.49.1 n.2.

84 Ibid. fol. $54 \mathrm{va}-54 \mathrm{vb}$ to $\mathrm{X} 1.6 .24$ n.4 S.v. subtractus. Note that the word 'subtractus' does not occur in the decretal; it should probably be changed to 'subtractam'.

${ }^{85}$ Ibid. fol. $157 \mathrm{rb}$ to X 1.33 .8 n.2 s.v. subiecte: 'et sunt in possessione earum: possessio enim sine cause cognitione nemini est auferenda: 12 quaestio 5 c. 1 [C.12 q.5 c.1]; 16 questio 6 c. Placuit [C.16 q.6 c.1(2)]; C. unde ui, Si quis in [Cod. 8.4.7]; C. si per vim 1. ultima [Cod. 8.5.2]'.
} 
discussed a transfer of 'dominium' in a decretal originating from the Fourth Lateran Council (X 3.49.8; can. 34), which prohibited prelates from extorting more from their subjects than is due, and which demanded restitution (and an equal donation to the poor). Towards the end of his commentary, Innocent raised the following question: could restitution be impeded if a prince were to make a decree against Ius naturale, say, that 'dominia' were to be transferred from one to another 'sine causa'? Innocent denied that the decree should be considered valid in either the 'forum animae' or the 'forum iudiciale'. In fact, he argued, even if the decree was due to a just cause, when the cause ceases, the decree should be limited to the particular case where the decree was just. ${ }^{86}$ In other words, a just cause might justify an otherwise untenable action such as the removal of the rights of ownership, but such a decree does not retain its force when the just cause no longer applies. Innocent in fact seems quite unwilling to endorse (quidam tamen alii dicunt) the more extreme view that a decree made contrary to Ius naturale, yet from just cause, should continue to be observed even after the just cause ceases to be. ${ }^{87}$ On this latter point, Innocent belongs to the mainstream tradition. ${ }^{88}$

${ }^{86}$ Ibid. fol. 461rb-461va to X 3.49 .8 n.5 s.v. restituat: 'uel alius princeps faceret aliquam constitutionem contra ius naturale, puta quod dominia de uno in alium transferrentur sine causa, si constitutio in foro anime esset seruanda? Et uidetur nobis quod non: imo nec in foro iudiciali quod plus est: ut notatur supra de constitutionibus, Que in [X 1.2.7]. Imo plus uidetur quod etiam si constitutio iusta fuerit ex causa, scilicet iusta, set illa causa iusta cessat in casu de quo modo agitur, uel in foro anime uel communi, tamen constitutio tantum restringenda est ad eum casum ubi fuit iusta constitutio: ut uerbi gratia, iusta constitutio quod dat exceptionem macedoniani propter iustam causam [Cod. 4.28 and 4.29; Dig. 14.6] Set si certum esset quod illa causa non subesset, ut, si in necessitate mutuasset, peccaret qui exceptione se defenderet'.

87 Ibid. fol. 461va n. 6: 'Quidam tamen alii dicunt quod ex quo facta est constitutio, licet contra ius naturale, dummodo iusta causa fuerit constitutionem illam faciendi, licet postea eueniat casus, ubi cessat causa iusta, tamen constitutio est seruanda, que generaliter fuit facta. Non potuit enim nec fuit etiam expediens omnes articulos sigillatim comprehendere, ff. de legibus ásenatusque consultis et longa consuetudineñ, non possunt [Dig. 1.3.12], nisi talis casus, qui a iure excipiatur'.

88 See André Gouron, 'Cessante causa, cessat effectus: À la naissance de l'adage', Académie des Inscriptions et Belles-Lettres. Comptes rendus des 
One place where Innocent especially discussed taking away rights was in the title 'On election and the power of the elect' (X 1.6). Here as elsewhere, Innocent wrote interchangeably of the right of electing (ius eligendi) and the power of electing (potestas eligendi), doubtlessly influenced by the terminology found in this title. ${ }^{89}$ At any rate, Innocent took the opportunity to discuss occasions when this power or right might be taken away. One example comes from a well known decretal about elections knowingly made of less than worthy candidates or by less than a numerical majority (X 1.6.22). Innocent spent some time considering what happens when people elect an unworthy candidate. If the electors acted with knowledge, Innocent explained, regardless of their numbers they are deprived of their power of electing by virtue of the law itself (ipso iure). The situation is different if the majority unknowingly elects an unworthy candidate. According to Innocent, since they did not sin by acting in ignorance, they do not lose their right of electing. ${ }^{90} \mathrm{In}$ a comment to a later decretal (X 1.6.40), writing about an election that has been rejected, Innocent made a similar point, even referring back to the previous decision. This time, while explaining the phrase 'maior pars', he again pointed out that a majority who elect an unworthy candidate lose their power of electing and those who remain thereby become the new majority. ${ }^{91}$

séances de l'année 1999, janvier-mars (Paris 1999) 305-309, for the earlier canonistic history. On the relationship between property rights and natural law see Tierney, Liberty and Law passim.

${ }^{89}$ E.g., the following all discuss someone being deprived of their 'potestas eligendi': X 1.6.7 § 3); X 1.6.20; X 1.6.23; X 1.6.25; X 1.6.43; and X 1.6.53.

${ }^{90}$ Innocent IV op. cit. fol. $51 \mathrm{rb}$ to $\mathrm{X} 1.6 .22(23)$ n.3 s.v. numerus: 'Et est huius diuersitatis ratio, quia quando eligitur indignus, quotquot scienter eum eligunt, ipso iure priuati sunt potestate eligendi; supra, eodem, cum in cunctis [X 1.6.7]. Unde tunc etiam in unum recidit ius capituli: 65 di. c. ult. [D. 65 c. 9]. Quando autem ignoranter eligit indignum maior pars, tenet electio facta a maiori parte, et hoc ideo, quia est sanior: infra, eodem, Congregato [X 1.6.53]. Et hic non autem ea ratione diximus tenere eam, quod in minorem partem reciderit ius eligendi, nam cum non peccauerunt, quia indignum ignorabant ius eligendi non amittunt: supra, eodem, Innotuit [X 1.6.20]'

${ }^{91}$ Ibid. fol. $69 \mathrm{vb}$ to $\mathrm{X} 1.6 .40$ n.6 s.v. maior pars: 'non intelligas quod, licet maior pars postulantium uel eligentium eligendo indignum scienter priuata sit 
What both these texts show us is a practical example of a case where people could be deprived of their right or power of electing if they elect someone they know to be unsuitable. It is, in other words, an example of a right being taken away through fault. That those who unknowingly elect an unworthy candidate are not so deprived suggests an implicit example of the 'sine culpa' clause.

Perhaps a more interesting decretal in this connection is the decretal Grandi. He commented on it as part of De supplenda negligentia praelatorum at X 1.10 .7 , but it was not officially included in a canonical collection until the promulgation of the Liber sextus (VI 1.8.2). Here the problem was a case of succession and a negligent king of Portugal. In the portion of his commentary that concerns us, Innocent noted that a king cannot deprive relatives of a kingdom by will alone, although the pope or someone superior to the king in question can so deprive 'ex causa', at least in a case where the kings are made through succession. ${ }^{92}$

In places where Innocent could have explained his thought by reference to 'sine culpa et sine causa', he never seems to have done so. Yet, it is also fair to suggest that he, like his predecessor of the same name, wished to keep the rights of his bishops (and others) inviolate. ${ }^{93}$ Sometimes this meant that Innocent defended

potestate eligendi, quod propter hoc alii, qui ignorantes eum indignum ipsum eligerent, eodem modo priuati sunt potestate eligendi. Set hoc ideo fuit, quia maior pars postulantium archiepiscopum indignum priuati sunt potestate eligendi, reliqui qui elegerunt plebanum sunt maior pars'.

92 Ibid. fol. $96 \mathrm{vb}$ to $\mathrm{X} 1.10 .17$ [= VI 1.8.2] n.1 s.v. regni: 'speciale est in regno, quod reges non possunt priuare, nedum filios, set nec fratres, uel alios consanguineos ex stirpe paterna descendentes, a regno sola voluntate, licet ex causa Papa, uel alius superior rege, possit eum priuare, infra, de uoto, Licet [X 3.34.6]. Et hoc est uerum, ubi reges deferuntur per successionem, set si per electionem defertur, secus est: supra, de electione, enerabilem [X 1.6.34]'. See also Innocent IV fol. 197va-198ra to X 2.2.10 n. 1-3; discussed in Brian Tierney, 'The Continuity of Papal Political Theory in the Thirteenth Century: Some Methodological Considerations', Mediaeval Studies 27 (1965) 233-234.

93 Thus, Ibid. fol. 436ra to X 3.36 .2 n.2 s.v. terminis: 'Ideo seruantur omnibus iura sua, quia locus unitus alii non mutat naturam suam, set si locus mutaret naturam suam, tunc acciperet iura annexa a iure uel consuetudine nature mutate, sicut est uidere in monasterio facto a capella, quod assumit iura 
greater rights (e.g., possessio) at the cost of lesser ones, ${ }^{94}$ sometimes, considerations of utility meant public law (ius) had to bend to custom. ${ }^{95}$

\section{Cardinal Hostiensis}

Cardinal Hostiensis, born Henry of Susa, despite his stronger hierocratic views, ${ }^{96}$ was a more vocal champion of individual rights than Pope Innocent IV. ${ }^{97}$ Perhaps this is yet further evidence of Cardinal Giovanni Panciroli's (1587-1651) observation that Hostiensis, 'aequitatis amator', was unafraid to challenge Innocent's opinions. ${ }^{98}$ There are two versions of his Lectura. The first was written ca. 1260. He finished his final version ca. 1270. For purposes of his thought about 'ius' I did not find his thought

competentia capelle, et cum suo preiudicio'. Innocent's gloss s.v. terminis is probably an additional gloss to the same word in X 3.36.1 that got added to the following canon in the course of the manuscript tradition. Innocent's Commentary developed in stages and he added many 'additiones'; see Martin Bertram, 'Zwei vorläufige Textstufen des Dekretalenapparats Papst Innozenz' IV.' Kanonisten und ihre Texte (1234 bis Mitte 14. Jh.): 18 Aufsätze und 14 Exkurse (Education and Society in the Middle Ages and Renaissance 43; Leiden-Boston 2013) 272-317 and Exkurse 528-530. Bertram prints a number of Innocent's 'additiones'.

${ }^{94}$ Ibid. fol. 538ra to X 5.33 .3 n.4 s.v. moniales: 'Nec mireris si per priuilegium faciliter tollitur ius, cuius possessio non habetur, quam possessio'. Cf. Inst. 4.15.4.

${ }^{95}$ Ibid. fol. 451ra to X 3.39.24 n.6 s.v.iteratione in glossa visitatiionem: 'imo plus uidetur quod etiam consuetudo illa que est contra ius publicum utilitate ex causa aliquando ualet, licet tunc tantum quando uel expresso consensu populi, uel tacito ex certa causa, 12 di. nos [D.12 c.8]'. The 'sometimes' is significant here, for the pope also pointed out that 'consuetudo' should not to be extended against 'ius', or if it is burdensome; see Ibid. fol. 117ra to X 1.23.10 n.6 s.v. predicto.

96 For biographical details, see K. Pennington, 'Enrico da Susa, cardinale Ostiense', DGI 1.795-798.

${ }^{97}$ In order to keep the discussion to a reasonable minimum, I have focused less on his Summa aurea. When I have cited the Summa I have used the Venice 1574 edition. For his Lectura I have used the Stasbourg 1512 edition that is superior to the Venice 1581 printing.

98 Panciroli, De claris legum interpretibus: 'Aequitatis amator, duras Innocentii opiniones libenter damnat . . .'; quoted in Tierney, Foundations 107. 
evolved perceptively from his earlier to his later Lectura. ${ }^{99}$

In what follows, it is worth bearing in mind that the 'iura' we are talking about are, except where noted, 'iura positiua', particularly those of Ius ciuile, which did not have the power to change Iura naturalia. ${ }^{100}$ In the case of (ecclesiastical) canons, what this means in practice is that the 'lator canonum', thinking terms of 'the truth of the justice' of Ius positiuum and Ius naturale, might need to forsake (deserere) the first, or even 'to temper and relax it from a just cause in order to avoid scandal'; alternatively, he might need to establish the contrary in certain cases. ${ }^{101}$ Given this view, it will not be surprising if we note that Hostiensis also believed that 'iura' have been, and continue to be, changed according to the times. ${ }^{102}$

One might be tempted to translate the use of 'ius' in the previous paragraph as 'law' rather than 'right'. In truth, either translation may well be appropriate; the point I am trying stress is

${ }^{99}$ See K. Pennington, 'An Earlier Recension of Hostiensis's Lectura on the Decretals', BMCL 17 (1987) 77-90. For a striking example how Hostiensis' thought evolved see Roberto Grison, 'Il problema del cardinalate nell'Ostiense', AHP 30 (1992) 125-157. For an edition of his Lectura on a decretal that illustrates the additions that Hostiensis made to his earlier recension, see Uta-Renate Blumenthal, 'A Gloss of Hostiensis to X 5.6.17 (Ad liberandam)', BMCL 30 (2013) 89-122.

${ }^{100}$ Hostiensis, Lectura to X 3.23.4 (Strasbourg 1512) fol. 74ra s.v. probandi: 'Nimirum ciuilia quidem iura, ciuilia tollere possunt, non utique naturalia, que nec tolluntur, nec mutantur per aliquod ius positiuum, instit. de iure naturali $\S$ Set naturalia [Inst. 2.2.11]; et instit. de legitima adgnatorum tutela, $\S$ fin. [Inst. 1.15.3]; C. de veteri iure enucleando 1.ii. § Set quia diuine [Cod. 1.17.2.18]'.

${ }^{101}$ Hostiensis, Lectura ed. cit. fol. 94vb to X 1.9.10 s.v. deserere: 'Nam distinguendum est inter ueritatem iustitie iuris naturalis, quod in lege et in euangelio continetur [cf. D. 1 d.a.c. 1], et hec propter uitandum scandalum non est deserenda, ut ibi [X 1.9.10] et ueritatem iustitie iuris positiui, quam quidem lator canonum potest et debet deserere, ut scandalum uitet, et ex iusta causa alia temeperare, et relaxare, et in certis casibus contrarium statuere, ut patet in eo quod legitur et notatur, infra, de concessione prebende, Proposuit [X 3.8.4]; infra de voto c.i. [X 3.34.1]; infra de statu monachorum, Cum ad monasterium $\S$ finali' $[X$ 3.35.6].

${ }^{102}$ See ibid. fol. 419ra to X 2.28 .46 s.v. set in modum denunciationis: 'et sicut variantur tempora variantur et iura'. Also fol. $57 \mathrm{rb}$ to X 1.6.29 s.v. a nominatione dicti archidiaconi recedentes. 
that positive 'ius' is mutable. However, that does not mean that Hostiensis thought that 'ius' should be interfered with arbitrarily. Hostiensis's take on positive rights might be said to begin with the Roman law maxim that pursuing one's 'ius' cannot cause injury. ${ }^{103}$ Usually, when Hostiensis used this argument, he referred the reader back to his comments to the decretal Cum ecclesia Vulterana (X 1.6.31). This decretal presents a case where a bishop elected some canons in a church where the resident canons did not want to accept the bishop's new canons. In his decision, Pope Innocent III sided with the canons, quoting fairly accurately from the Digest (Dig. 50.17.55): 'because, (just as a 'regula iuris' says,) "he who uses his own right does not seem to cause injury"., 104 The relevant gloss here provides a list of references making a distinction based on whether one acts with or without an intention of causing harm (animus nocendi), but it does not make any reference to the question of rights. ${ }^{105}$ Hostiensis connected these

${ }^{103}$ See, e.g. ibid. fol. $133 \mathrm{v}$ to X 2.2.17 s.v. respondere: 'Ergo si iurisdictionem suam comittit alii nemini facit iniuriam'. Cf. fol. 432 r to X 2.28 .62 s.v. errorem: 'quia iuris ignorantia non obest suum ius prosequenti'. for the point that even 'ignorantia iuris' should not prevent one from prosecuting his or her ius. The relevant Roman texts are: Dig. 50.17.55: 'Nullus videtur dolo facere, qui suo iure utitur'; and Dig. 50.17.155.1: 'Non videtur vim facere, qui iure suo utitur et ordinaria actione experitur'.

${ }^{104}$ X 1.6.31: 'quia, sicut iuris regula dicit, non videtur iniuriam facere qui utitur iure suo'. Note that words set it italics were not part of the medieval vulgate edition of the Liber extra because Raymond de Peñafort omitted them from the text of the decretal in 3 Comp. 1.6.16. On Raymond's editing of the decretals, see Edward Reno III, The Authoritative Text: Raymond of Penyafort's editing of the Decretals of Gregory IX (1234) (Ph.D. dissertation, Columbia University 2011).

105 Bernardus Parmensis (Ordinary Gloss) to X 1.6.31 s.v. iniuriam: 'Simile ff. de iniuriis, Iniuriarum $\S$ i. [Dig. 47.10.13.1]; et ff. de petitione hereditatis, Illud i. responso in fine [Dig. 5.3.40(43)]; et infra de appellationibus, Bone [X 2.28.51]; et xiv. q.i. Quod debetur [C.14 q.1 c.2]; et q.v. Non sane [C.14 q.5 c.15]; quia etiam si noceat alii: ita ut auferat ei consueta commoda: dum tamen non faciat animo nocendi: non dicitur facere iniuriam; ff. de aqua pluvie arcende, $\mathrm{Si}$ in meo [Dig. 39.3.21] et ff. de damno infecto, Proculus [Dig. 39.2.26]; et xv. q.i. Illud [C.15 q.1 c.2], ff. de servitutibus urbanorum prediorum, Cum eo [Dig. 8.2.9(8)]; et xxiii. q.ii. c. ultimo [C.23 q.2 c.3]; secus si faceret animo nocendi; ff. de regulis iuris, Domum [Dig. 50.17.61(62)], ff. de 
two considerations in his commentary. According to Hostiensis, 'anyone can use his own right without the intention of causing harm, even if if he takes away the accustomed advantages of another'. ${ }^{106}$ Hostiensis agreed with Innocent III: it pertained to the residing canons to create new ones, not the bishop; in acting as they did they were merely using their own right. ${ }^{107}$ There is a clear sense that to have a ius in this case was to have the freedom to act, not an obligation to do so. ${ }^{108}$ It would have been possible for the canons to have let the bishop create new ones.

Hostiensis not only thought that rights can be used, which hardly seems a novel position to take - he also thought they should not be taken away too easily: iura should be preserved where possible. Hostiensis mentioned it in passing as a general obligation all people have, ${ }^{109}$ but it is clearest in the decretal $\mathrm{Ad}$ haec sumus (X 1.3.10), where Pope Lucius III stripped some circulating letters of their authority. A gloss suggested that it was due to letters being directed to uncertain judges, which Hostiensis

damno infecto, Qui uias [Dig. 39.2.31]; ff. si servitus vindicetur, Sicut $\S$ Aristo [Dig. 8.5.8.5]'.

${ }^{106}$ Hostiensis, Lectura to X 1.6 .31 fol. $59 \mathrm{r}$ s.v. iniuriam facere: 'Similiter ff. de iniuriis, Iniuriarum $\S 1$ [Dig. 47.10.13.1] et de regulis iuris, Nemo damnum, penultima columna [Dig. 50.17.151] et de petitione hereditatis, Illud [Dig. 5.3.40 pr.] et infra, de appellationibus, Bone [X 2.28.51], xiv. q.i. Quod debetur [C.14 q.1 c.2] et q.v. Non sane [C.14 q.5 c.15], lxiiii. di. Quia per ambitiones [D.64 c.6]. Nam suo iure uti potest quis sine nocendi animo, etiam si alii auferat commoda consueta, ut ff. deseruitutibus urbanorum prediorum, Cum eo [Dig. 8.2.9(8)], xxiii. q.ii. c.ult. [C.23 q.2 c.3]; C. de servitutibus, Altius [Cod. 3.34.8]. Secus si hoc faceret animo nocendi, non sibi prouidendi, ut ff. de regulis iuris, Domum [Dig. 50.17.61(62)] et de damno infecto, Qui uias [Dig. 39.2.31]'. Cf. the more objective claims: Lectura to X 2.28.2, fol. 401v s.v. redarguimus: 'Notatur illum, qui contra ius facit, redarguendum esse ut hic et supra de usu pal. Nisi [X 1.8.3]'; and Lectura to X 1.9.10, fol. $94 \mathrm{r}$ s.v. remanerent quoting C. 23 q. 4 c. 40 'nemo peccat legis autoritate'.

${ }^{107}$ Hostiensis, Lectura to X 1.6.31 fol. 59r s.v. iure suo.

${ }^{108}$ Cf. the parallel discussion in Reid, 'Thirteenth-Century Canon Law and Rights' 311-312, 314.

${ }^{109}$ Hostiensis, Lectura to X 3.31.18, fol. 120r s.v. iusto: 'in hoc casu. Alias enim non est etiam iudex nisi sit in eo iusticia, infra de verb. sign. Forus [X 5.40.10] et quilibet astrictus est seruare iura, supra de constitutionibus c.i. [X 1.2.1] et c. Ne innitaris [X 1.2.5] et c. finali [X 1.2.13]'. 
was happy to entertain as well. ${ }^{110} \mathrm{Had}$ he had a fuller version of the letter, he would have learned that the pope thought the letters either did not emanate from the papal chancery, or were sent before he had had time to consider them more carefully. ${ }^{111}$ Hostiensis was clearly not aware of this problem, but he thought the basic idea that 'rights of an ordinary authority (ordinariae potestatis) ought to be safe-guarded' need not apply here for two possible reasons: either because the action was done with certain or sure knowledge, or because he, i.e., the pope, had entrusted a general embassy. ${ }^{112}$ The second exception is rather opaque, but the reference points to the decretal Sane si a nobis (X 1.29.2), which sets down that when conflicting letters are submitted to judges, they are to be left alone until the pope has been consulted.

Generally speaking, however, rights are to be safe-guarded rather than corrected where possible. In a discussion about the restitution of a church in a case of an enormous loss (X 3.13.11), Hostiensis argued that while restitution might not be given for small things, this is not true when there is an enormous injury (enormen laesionem). More interesting to us, perhaps, is the point he made about correcting rights. It is, he wrote, against the law (lex; viz, Cod. 3.30.1) for iura to be corrected instead of safeguarded. ${ }^{113}$ Elsewhere, again in relation to the Code (via Gregory

110 Bernardus Parmensis, Glos. ord. to $\mathrm{X} 1.3 .10$ s.v. eligerint; Hostiensis, Lectura to X 1.3.10 fol. 12r s.v. eligerint.

${ }^{111} \mathrm{X}$ 1.3.10.

112 Hostiensis, Lectura to X 1.3.10, fol. 12r s.v. nostra auctoritate: 'Hec tamen litera contradicit, et quia seruanda sunt iura ordinarie potestatis, infra de appellationibus, Ut debitus cum suis concordantibus [X 2.28.59] et xi. q.i. Peruenit [C.11 q.1 c.39] nisi appareret quod ex certa scientia hoc fieret, ix. q.iii. Nunc uero [C.9 q.3 c.20]; uel nisi generalem legationem committeret, infra de officio delegati c.ii. [X 1.29.2]'.

${ }^{113}$ Idem. to X 3.13.11, fol. 59r s.v. enorme: 'Alii autem intelligunt quod hic tenuit contractus, quia legitimus consensus illorum, qui in talibus requirendi sunt, scilicet abbatis, et conuentus interuenit, set restituitur propter enormem lesionem, et huic concordat dominus noster; et secundum hunc intellectum hec littera planius sonare uidetur. Set si sic intelligas, corriguntur iura, que in talibus requirunt consensum diocesani, ut nota supra c.i. [X 3.13.1] et fulcitur opinione G. Na. [Guillelmi Naso] que communiter reprobatur. Nam certi sumus, (qui et factum nouimus) quod plusquam per decem annos post 
IX) - namely, that the pope should not be thought to want to overturn all the iura he oversees (tuetur) $)^{114}$ - Hostiensis noted that there is a reason for this: because we should be prompt to safeguard rights, rather than to correct them. ${ }^{115}$

Yet, while Hostiensis deserves recognition for defending the sanctity of rights, we should note what normative force he applied in these passages. His point was that rights should not normally be taken away, and that we should be readier to defend than to correct a person's or a corporation's rights. But the exercise of one's rights is not always something that deserves to be defended. To take one example, Hostiensis noted that it would be better for a person to desist from his right in order to avoid a scandal. In this case, however, Hostiensis was quoting almost verbatim from a gloss, which suggests that he agreed with what was probably the consensus view. ${ }^{116}$

This brings us finally to the question of the 'sine culpa et sine causa' principle. Given his seemingly robust support of the basic sancity of rights, it is natural that Hostiensis generally defended the idea that rights should not be taken away without fault. In his Summa aurea, for example, we find him echoing what Innocent III had written regarding the marital debt: a wife's right

tempus contractus numerandos tenuit iste laicus uillam istam, nec placet, quod iura, que saluari possunt, corrigantur, quia est contra legem, C. de inoffic. dotibus l.unica [Cod. 3.30.1]'.

${ }^{114}$ Cf. Cod. 3.28 .35 pr.: 'neque enim credendum est romanum principem qui iura tuetur huiusmodi verbo totam observationem testamentorum multis vigiliis excogitatam atque inventam velle everti'; and $\mathrm{X}$ 1.6.57: 'Neque enim credendum est, Romanum Pontificem, qui iura tuetur, quod alias excogitatum est multis vigiliis et inventum, uno verbo subvertere voluisse'. Hostiensis noted that the text was different in the Codex his commentary on the decretal ('alias neque') by reference to this passage in the Code.

115 Hostiensis, Lectura to X 1.6.57, fol. 83v s.v. nec enim: 'alias 'neque'; et sumuntur hec uerba ex lege $\mathrm{C}$. de inofficioso testamento, Si quando [Cod. 3.28 .35 pr.] et est argumentum quod non debemus esse prompti ad iura corrigenda set potius saluanda, C. de inofficiosis dotibus, 1. unica [Cod. 3.30.1]'. See also Hostiensis, Lectura to X 3.49 .2 for the point that the privileges of emperors should be safe-guarded as well.

${ }^{116}$ Cf. Hostiensis, Lectura to X 2.26.2, fol. 377r s.v. Nihil cum scandalo: and Bernardus Parmensis, Glos. ord. to X 2.26.2 s.v. Nihil cum scandalo. 
should not be taken away when she was not at fault. ${ }^{117}$ It was a different matter, however, when there was a reasonable or just cause. ${ }^{118}$

When he treated the idea of 'sine culpa' and 'ius', Hostiensis first took it up in the then-standard place in his Commentary on the decretal Cognoscentes. Hostiensis opened his commentary at this point with the plea that one who lacks fault should lack the penalty 'with me as the judge', which was a point repeated by Johannes Andreae in the next century. ${ }^{119}$ Yet, as this may not be always possible, although it may be serious to deprive someone of their right 'sine culpa', ${ }^{120}$ there may nevertheless be reasons to do so. Bernardus Parmensis listed six cases when a person might be deprived of a 'ius' 'sine culpa'. Hostiensis provided what Bernardus had not: a legal justification for each. At the end of his analysis, he made the expected point: ${ }^{121}$

${ }^{117}$ Hostiensis, Summa aurea to X 4.13, col. 1346: ‘ . . . nec uxor priuabitur iure suo sine culpa sua'.

${ }^{118}$ E.g., Hostiensis, Lectura to X 4.9.1, fol. $217 \mathrm{v}$ s.v. neque liber defended the point that a servant should not be compelled to pay since it would be the lord who paid, and 'non debet dominus priuari iure suo sine culpa sua'. See also Lectura to X 2.27.3, fol. 386v s.v. concors (bis) which denied 'sine culpa' when there is a just cause.

${ }^{119}$ Hostiensis, Lectura to X 1.2.2, fol. 16r s.v. culpa: 'qui caruit culpa, careat me iudice poena: quia "quod legitime factum est, penam" non 'meretur': C. de adulteriis et de stupro 1. Graccus [Cod. 9.9.4]'. Johannes Andreae, In quinque Decretalium libros, with an intro. by S. Kuttner (4 vols. Venice 1581, reprinted Turin 1963) to X 1.2.2, fol. 12va s.v. meretur.

${ }^{120}$ Hostiensis, Lectura to X 3.38.20, fol. 155r s.v. facta: 'Set et quia graue est aliquem priuare iure suo sine culpa sua, lvi. di. Satis peruersum [D.56 c.7], requiritur consensus patroni ad hoc, ut ecclesia collegiata fiat, ut supra, de consuetudine, Cum dilectus $\S$ Dictus [X 1.4.8]'.

${ }^{121}$ Hostiensis, Lectura to X 1.2.2, fol. 16r s.v. culpa: 'Set nec priuatur aliquis iure suo sine culpa, lvi. di. Satis peruersum [D.56 c.7], xvi. q.ult. Inuentum [C.16 q.7 c.38]; set contra: xxxiiii. di. Si cuius [D.34 c.11], et capitulo sequenti [D.34 c.12]; xxvii. q.finali Multorum [C.27 q.2 c.20]. Solutio in uersibus sequentibus: paupertas: xvi. q.i. Et temporis qualitas [C.16 q.1 c.48]; odium: XXv. q.ii. Ita nos [C.25 q.2 c.25]; uicium: infra de clerico debilitato, Tua nos [X 3.6.4]; fauor: xxii. di. Renouantes [D.22 c.6]; et scelus: ut in contrariis et xxiiii. q.iii. Si habes [C.24 q.3 c.1], infra de sponsalibus, Non est [X 4.1.11]; ordo: liiii. di. Frequens [D.54 c.10] 〈et〉 Generalis [D.54 c.12]; ff. de operis 
Or, more briefly: he is not deprived, etc., without fault - or without cause, as below, X 2.6.5 $\S 2$. On all this, it is noted in my Summa, De poenis $\S$ In quibus sub $\S$ Est autem poena imponenda.

For Hostiensis, it was the 'sine causa' principle that played a more important role. For instance, in a comment to Ex literis (X 2.4.1), a decretal which allows the judge delegate to terminate a lawsuit and its counter-suit (causa reconventionis) with a single judgment, Hostiensis agreed with the ruling. ${ }^{122}$ But in the ensuing commentary, he suggested another possibility: that the second case be suspended for a time 'ex causa'; nor, Hostiensis continued, 'do I think this absurd: for a petition is not only suspended in other situations 'ex causa', but someone is even deprived of his right without his fault'. ${ }^{123}$

Another example can be found in his commentary on $U t$ debitus honor (X 2.28.59), a decretal which limited appeals to higher courts while a case was still pending. Hostiensis employed

libertorum, Interdum [Dig. 38.1.51]; Personas spoliant, et loca iure suo: uel breuius non priuatur, etc. sine culpa, uel sine causa, ut infra, ut lite non contestata, Quoniam frequenter $\S \mathrm{Si}$ vero $\left[\begin{array}{llll}\mathrm{X} & 2.6 .5 & \S & 2\end{array}\right]$. De hoc notatur in Summa, de poenis, § In quibus, sub $\S$ Est autem pona imponenda'. See Hostiensis, Summa aurea to X 5.37 col. $1738-1739$ n. 8 s.v. Que et quibus, where he quoted the same verse and used many of the same references, albeit in the context of a discussion about how one is usually not punished for the offence (delictum) of another.

${ }^{122}$ Hostiensis, Lectura to X 2.4.1, fol. 238r s.v. incontinenti.

${ }^{123}$ Ibid.: 'Set nec absurdum reputo, si de actione de nouo orta non agatur, set ad tempus ex causa suspendatur, ut maior absurditas euitetur, que contingeret, si coram diuersis iudicibus eodem tempore ageretur, ut patet in eo quod legitur. Et notatur supra, de rescriptis, Quia nonnulli [X 1.3.43]. Set nec insaniam reputo huic reo iudices ordinarios actoris ad tempus subtrahere. Imputandum est enim ei quia non conuenit eum antequam conueniretur ab eo et subueniendum illi, qui uigilauit et sibi prouidit, argumentum infra, de appellationibus, Ut debitus [X 2.28.59] et ff. de his que in fraudem creditorum, Pupillus ad finem [Dig. 42.8(9).24]. Cum ergo natura iudicii non patiatur, quod talis reconuentio fiat, set ex causa suspenditur petitio. Non reputo hoc absurdum: nam et alias ex causa non solum suspenditur, set et priuatur quis iure suo sine culpa sua, ut patet in eo, quod legitur, et notatur infra ut lite non contestata, Quoniam § Si uero aliter uersu fimali [X 2.6.5 § 2]. Nec dicas quod in lege allegata, cuius in agendo, non fiat mentio de lite contestata. Sit enim ibi de hoc mentio quando dicitur in eodem negocio, quod expone: i.e. iudicio siue instantia iudicii: argumentum infra, de uerborum significatione, Forus $\S$ Negocium' [X 5.40.10]. 
the 'sine culpa' principle to defend the idea that rescripts would be valid if they had already been assigned to a (judge) delegate: ${ }^{124}$

For it would be absurd that a requested rescript should lose its force where there was no deceit by the person who made the request, or where negligence cannot be imputed, above X 1.3.23; for no one is to be deprived of his right without his fault, D. 56 c. 7 - unless something be established in favor of an ordinary authority, as noted and argued above in what is read and noted above $X$ 1.2.2. above $X$ $2.6 .5 \S 2$, at the end.

Hostiensis applied in this passage the teaching of Bernardus Parmensis' verse in his Glossa ordinaria, 'fauor', which perhaps would be best translated as 'preference for'. It was one of the six general causal exceptions to the 'sine culpa' proviso. If it seems a tenuous reason nowadays, for Hostiensis it was reasonable to think that ecclesiastical favor might necessarily result in a loss of rights for others.

Another important discussion can be found in the comment to Ex transmissa (X 1.17.7), one of the decretals to deal with the problem of hereditary succession to a church. At the end of his commentary, Hostiensis posed a series of hypothetical questions. One of them supposed two churches that were led by relatives and united due to their poverty (propter ipsarum tenuitatem): if one of the two related rectors should die, would the other succeed? Here, Hostiensis stressed the importance of just cause: ${ }^{125}$

124 Hostiensis, Lectura to X 2.28.59(58), fol. 428v s.v. delegato fuerint: 'Absurdum enim esset, quod rescriptum impetratum amittat uires suas, ubi non potest impetranti dolus, uel negligentia imputari, supra de rescriptis, Plerumque [X 1.3.23]. Cum nemo iure suo priuandus sit sine culpa sua, lvi. di. Satis peruersum [D. 56 c. 7], nisi in fauorem potestatis ordinarie aliud statuatur, ut supra notatur et arguitur in eo quod legitur et notatur supra de constitutionibus, Cognoscentes [X 1.2.2], supra, ut lite non contestata, Quoniam $\S$ Si uero in fine' [X 2.6.5 § 2].

${ }^{125}$ Hostiensis, Lectura to X 1.17.7, fol. 120v s.v. successionem: 'Nec obstat si dicas quod non est quis priuandus iure suo sine culpa sua, ut supra, de constitutionibus, Cognoscentes [X 1.2.2], lvi. di. Satis peruersum [D.56 c.7]: quia subaudiendum est, uel sine iusta causa, infra ut lite non contestata, Quoniam frequenter $\S$ Si uero aliter [X 2.6.5 § 2]. Hic autem subest hec, scilicet quia unus non debet alteri immediate succedere, ut dictum est supra'. In fact, Hostiensis went on to deny that one had the 'ius' as claimed, but his contra 
Nor does it oppose [scil. that the survivor should not succeed automatically] if you say that someone is not to be deprived of his right without his fault, as above, X 1.2.2; D.56 c.7: because 'or without just cause' is to be supplied: below, as in X 2.6.5 $\S 2$, at the end. Here, moreover, this [cause] is present: namely, because one ought not immediately succeed the other, as was said above.

Here again we see Hostiensis' willingness to explain that although there was an apparent lack of fault in the decision, it was not made 'sine causa'. In another case, Hostiensis argued that a vassal of a fief could lose it, albeit temporarily, without fault if the fief is left by the lord to a church. The vassal would need to be to be reinvested in this situation. ${ }^{126}$

We can sum up, I think, Hostiensis's position in the following way. While rights should not be taken away without fault lightly, they are not to be taken away without cause. Two final examples bear out this statement. One comes from Suggestum est (X 3.38.20), which deals with the case where a second concession for a church, which is made by both bishop and patron, can supersede an earlier one made by the patron alone. ${ }^{127}$ It is clear that in such a case, the patron loses his 'ius patronatus', that is, the right of presentation to a vacant ecclesiastical office. Hostiensis did not see any problem: ${ }^{128}$

And so the 'ius patronatus' is lost even without fault, but not without cause: e.g., for favor of the church and for favor of ecclesiastical liberty, above X 2.6.5 $\S 2$, at the end; and because it is tolerated from grace rather than owed from justice, as is clear in that which is noted

argument does not affect the conclusion of this argument, which he seems to have believed was valid enough.

${ }^{126}$ Hostiensis, Lectura to X 3.13.12, fol. 59v s.v. destitutionibus: 'Intantum etiam in tali casu potest relinqui feudum ecclesiis ab illo, a quo tenetur ut uasallus ipsum retinere non possit, nisi ab ecclesia, cui relictum est, de nouo inuestiatur, et hic est casus, in quo quis amittit feudum sine culpa sua, in Libro feudorum, de pace iuramento firmanda l. unica § penultimo [L.F. 2.53.1].

${ }^{127}$ X 3.38.20.

128 Hostiensis, Lectura to X 3.38.20, fol. 155r s.v. facta: 'Et sic ius patronatus amittitur et si sine culpa, non tamen sine causa, puta fauore ecclesie et ecclesiastice liberatis: supra, ut lite non contestata c. finali § Si uero aliter [X 2.6.5 §. 2], uersu finali et quia potius toleratur de gratia quam de iustitia debeatur, ut patet in eo quod notatur supra, eodem Quoniam responsione i. in principio [X 3.38.3]'. 
above X 3.38.3, first response, at the beginning.

Hostiensis again applied the 'fauor' exception. A 'ius patronatus' may well be lost if it might interfere with the need for ecclesiastical liberty. Related to this is Hostiensis's comment to Nisi cum pridem (X 1.9.10). On a section where Innocent III wrote that sometimes a prelate is compelled to cease the government of his church due to the malice of the populace, ${ }^{129}$ Hostiensis agreed. His reference to three 'capitula' of the Decretum, which deal with the changing of bishops in cases of necessity (C.7 q.1 c.34-36), make it clear what 'cause' he had in mind when he said, 'for someone is deprived of his right with cause'. ${ }^{130}$

\section{William of Ockham}

If we turn to Ockham's political writings, we see a different use of the 'sine culpa et sine causa' principle. For the most part, both 'without fault' and 'without cause' are used in tandem and seem to carry approximately the same importance. ${ }^{131}$ Ockham employed

129 X $1.9 .10 \S 5$ : 'Propter malitiam autem plebis cogitur interdum prelatus ab ipsius regimine declinare, [et] quando plebs adeo dure cervicis exsistit, et in rebellione sua ita pertinax invenitur, ut proficere nequeat apud ipsam, set propter eius duritiam, quo magis proficere satagit, eo magis iusto iudicio deficere permittatur, dicente Domino per Prophetam: "Linguam tuam adherere faciam palato tuo, quia domus exasperans est", $\langle$ Ezech. 3:26〉 et Apostoli leguntur dixisse Iudeis: "Ecce convertimur ad gentes, quia verbi Dei vos indignos fecistis" [Act. 13:46]'.

${ }^{130}$ Hostiensis, Lectura to X 1.9.10, fol. 94 s.v. interdum: 'Hoc ideo dicit, quia non semper, ut infra eodem, uerso 'non tamen pro qualibet' [X $1.9 .10 \S 5]$ et quod dicit cogitur, intelligitur causatiue. Similiter notatur supra, de electione et electi potestate, Cum inter R. seniorem [X 1.6.16]; uel forte precise, cum magis prouidendum sit ecclesie quam persone. Unde saltem est ad aliam in qua proficere possit ecclesiam transferendus: quia non mutat sedem, qui non mutat mentem, vii. q.i. Scias [C.7 q.1 c.35], et c. sequenti [C.7 q.1 c.36] et precedenti [C.7 q.1 c.34] nam et ex causa priuatur quis iure suo, infra ut lite non contesta, Quoniam frequenter $\S \mathrm{Si}$ autem de carnali [X 2.6.5 §. 4]. Ad hoc, infra de rerum permutatione, Quesitum $\S$ finali [X 3.19.5]'.

131 Abbreviations for Ockham's works follow the de facto standard provided in P. V. Spade, 'Introduction', The Cambridge Companion to Ockham, ed. P. V. Spade (Cambridge 1999) 5-11. All but parts of the Dialogus are now edited in H. S. Offler et al. ed. Guillemi de Ockham opera politica, 9 (projected) vols. 
this principle throughout his political thought: it governed, he thought, basic property relations, the limits of secular and ecclesiastical interference in the affairs of their subjects, the relationship of pope and emperor, even the nature of the pope's fullness of power. It first surfaced in his defence of poverty, but then was applied throughout his Opera politica.

As one of several Franciscans involved in defending (as they saw it) their traditional vow of evangelical poverty from Pope John XXII's attempt to overturn the ideal, Ockham and his fellow Michaelists developed a cogent theory of property rights. ${ }^{132} \mathrm{In}$ doing so, he relied on 'sine culpa et sine causa' in a crucial discussion about the term ius utendi, which was one of a few terms on which the later stages of the poverty controversy turned. The text reads as follows: ${ }^{133}$

It is also clear that no one unwilling ought to be deprived of such a ius utendi without fault and without reasonable cause. For every ius utendi is a ius; but no one ought to be deprived of his own ius without fault and without reasonable cause, as the Gloss notes in X 1.2.2, X 4.13.11, and D. 22 c. 6 - as it is also clearly gathered from the sacred canons.

At this point in the treatise, Ockham was defending what he called a "positive right of using," and it was a key characteristic of such rights that their possessor could take legal action if wrongly

(Manchester \& Oxford 1956-); for the unedited portions, I have relied primarily upon William of Ockham, Opera plurima, 1: Dialogus de imperio et pontificia potestate (1494, reprinted Farnborough 1962), but I have also often consulted John Kilcullen et al. eds., William of Ockham: Dialogus (The British Academy 1995-), http://www.britac.ac.uk/pubS/ dialogus/ockdial.html.

132 See most recently, Jonathan Robinson, William of Ockham's Early Theory of Property Rights in Context (Studies in Medieval and Reformation Traditions, 166; Leiden 2012).

133 OND 61.55-59 (2:559-60): 'Quod etiam tali iure utendi nullus sine culpa et absque causa rationabili debeat privari invitus, patet. Nam omne ius utendi est ius. Nullus autem sine culpa et absque causa rationabili debet suo iure privari, ut notat glossa, Extra, de constitutionibus, c. ii, et Extra, de eo, qui cognovit consanguineam uxoris suae, c. ultimo, et di. xxii, c. Renovantes, et ex sacris canonibus colligiur evidenter'. For the text of the relevant glosses, see nn. 70,71 , and 68 , above. 
deprived of them. ${ }^{134}$ Ockham was in effect linking the ius utendi and the ius agendi, which John XXII had claimed were fundamentally and conceptually separate. ${ }^{135}$

It should perhaps be mentioned briefly that this emphasis on the basic inviolability of rights was somewhat novel from the Michaelist perspective. The closest analogue we have comes from Michael of Cesena's Munich appeal, likely ghost-written in large part by the legally trained Bonagratia of Bergamo. ${ }^{136}$ In the appeal, we read at one point that, 'no one is to be deprived of his own thing and the power of doing what he likes with it without his fault'. But Michael here was making an argument about monks lacking proprietas, since an abbot does decide when and how monks use things, and thus only accidentally defending the sanctity of individual property rights. ${ }^{137}$ It is interesting, too, that Michael's argument relies on Satis peruersum (D.56 c.7) and Inuentum est (C.16 q.7 c.38), which were important in the decretalist tradition, but were never cited in Ockham's political works. Conversely, none of the other Michaelists ever referred to the other three glosses, let alone the texts that they were glossing.

In subsequent writings, Ockham did not always list his canonistic sources. On one occasion, however, he added to the list.

${ }^{134}$ OND 61.34-69 (2:559-560); cf. 3.397-400 (321).

135 Quia vir reprobus, in G. Gál and D. Flood ed. Nicolaus Minorita: Chronica: Documentation on Pope John XXII, Michael of Cesena and The Poverty of Christ with Summaries in English. A Source Book (St. Bonaventure, NY 1996) 581; cf. Quia quorundam mentes, in Jacqueline Tarrant, ed. Extravagantes Iohannis XXII (MIC, Series B: Corpus collectionum, 6; Rome 1983) 264-267.

${ }^{136}$ Eva Luise Wittneben, Bonagratia von Bergamo: Franziskanerjurist und Wortführer seines Ordens im Streit mit Papst Johannes XXII (Studies in Medieval and Reformation Thought, 90; Leiden 2003).

${ }^{137}$ Appellatio monacensis, in Gál, Flood eds., Nicolaus Minorita: Chronica 815816: 'Et per consequens [sc. if Benedictine monks had things quoad proprietatem] abbates non possent prohibere monachis ne de talibus rebus ad vitam necessariis facerent quod videretur eisdem, quia re propria et potestate faciendi de ea quod placet nullus privandus est sine culpa sua, 56 D. c. [7] Satis perversum; et 16 q. [7] ultima, c. [38] Inventum, quod dicere vel sentire est omnem religionem voventem vivere sine proprio destruere et annullare, cum vivere sine proprio sit ea quae ad vitam pertinent, non habere propria'. 
In An princeps (1338-1339), he referred to the decretal Novit (X 2.1.13), while discussing the limitations of papal power; ${ }^{138}$ and in the Octo quaestiones (1340/41), he seemingly quoted from the De regulis iuris appended to the Liber sextus (VI 5.13. reg. 23) in a similar discussion of the pope's supposed fullness of power. ${ }^{139}$ It is clear that Ockham fully inculcated 'sine culpa et sine causa' and made it a distinctive cornerstone of his political philosophy.

Ockham usually cited 'sine culpa et sine causa' when he was trying to highlight the limits to the political power wielded by spiritual and temporal rulers. The poverty controversy provided the context for considering interpersonal relations: among equals it was fairly self-evident that one person should not be able to deprive another of his or her ius arbitrarily. It was precisely this idea that leveraged individual Franciscan rightlessness, since it was taken as axiomatic that friars were not legal persons. The interpersonal relationship of a Franciscan and someone else was, a priori, not a meeting of equals.

In the Breviloquium, Ockham had the occasion to consider the nature of individual rights between persons not normally subject to another's authority. The discussion takes place in the context of considering the distinction between exercising some form of political authority casualiter or regulariter, especially as related to the decretal Per uenerabilem (X 4.17.13), where Innocent III famously claimed he exercised temporal jurisdiction casualiter. ${ }^{140}$ Ockham wrote often about the regulariter casualiter distinction, which other scholars have treated at length. ${ }^{141}$ Here, Ockham employed the sine culpa principle to help

\footnotetext{
138 AP 5.57-59 (1:244).

${ }^{139} O Q 2.2 .13-21(1: 70)$.

${ }^{140}$ See Kenneth Pennington, 'Pope Innocent III's Views on Church and State: A Gloss to Per Venerabilem', Law, Church, and Society: Essays in Honour of Stephan Kuttner: Essays in Honour of Stephan Kuttner, edd. K. Pennington and R. Somerville (Philadelphia 1977) 49-67, reprinted with corrections, K. Pennington, Popes, Canonists, and Texts 1150-1550 (Variorum Collected Series Studies, CS412; Aldershot 1993) IV.

${ }^{141}$ Bayley, 'Pivotal Concepts'; de Lagarde, La naissance 4:184-189; McGrade, Political Thought 78-80, 92-95, 139-40; J. Miethke, De potestate papae: Die päpstliche Amtskompetenz im Widerstreit der politischen Theorie von Thomas
} 
explain what these two adverbs mean: ${ }^{142}$

Likewise, no one is to be deprived of his right without fault regularly; and yet he can be deprived on occasion; therefore, someone can have the power of depriving another person of his right without his fault on occasion, though he does not regularly have the power of depriving him of his right without his fault.

Ockham went on to say that this is much like the case of a servant or slave not regularly being able to detain his lord physically or otherwise bring force to bear, even though they might do so according to Augustine - 'casualiter'. That is, in certain cases, it is possible that someone would have a reason (causa) to infringe upon the rights of other people, but that should only occur in extraordinary situations.

Perhaps it is only natural to imagine that equals should respect each other's rights, but Ockham's preoccupation with separating the spheres of Church and empire meant he spent no less time analyzing unequal power relationships, and he frequently demonstrated the limits of political authority by reference to 'sine culpa et sine causa' This is especially true with regard to the question of the papacy and whether the pope should be thought to have a fullness of power.

Discussions of a pope's fullness of power invariably need to engage with Christ's promise to Peter in Matthew 16:19 regarding the power of loosing and binding. ${ }^{143}$ Ockham twice used 'sine culpa et sine causa' to limit the unmitigated fullness of power the biblical verse might seem to convey. In the Breviloquium, for instance, the principle is deployed as part of an argument that 'the legitimate rights of emperors, kings, and all the others, believers

von Aquin bis Wilhelm von Ockham (Spätmittelalter und Reformation. Neue Reihe, 16; Tübigen 2000) 187-188; and Shogimen, Ockham and Political Discourse 235-242.

${ }^{142}$ Brev. 4.4.11-14 (4:201): 'Item, regulariter nullus privandus est iure suo sine culpa, et tamen casualiter potest [privari]; ergo potest quis casualiter habere potestatem privandi alium iure suo sine culpa sua, quamvis non habeat regulariter potestatem privandi ipsum iure suo sine culpa sua'. Cf. $O Q 1.17 .113$ $126(1: 62)$

143 'Et tibi dabo claves regni caelorum et quodcumque ligaveris super terram erit ligatum et in caelis et quodcumque solveris super terram erit solutum et in caelis'. 
and unbelievers', that is, at least those 'which do not oppose good customs, the honor of God, or the observance of the evangelical law', should be exempted from the 'whatsoever' of Matthew 16:19. Thus the conclusion that 'the pope cannot regularly or ordinarily disturb or lessen in any way such rights by the power immediately given to him by Christ without cause and without fault'. Moreover, any such de facto action against those rights is to be considered invalid. ${ }^{144}$

The account given here is largely negative: it amounts to a conclusion about what the pope cannot do. Other examples he used were meant to show the practical and uncontentious limits to his power. In the normal course of affairs, he argued, the pope could not do any of the following: forcibly divorce a consumated marriage; ${ }^{145}$ force sexual abstinence or fasting; ${ }^{146}$ or impose further burdensome obligations related to religious practice. ${ }^{147}$ The flip side of the Matthean verse is that when the situation warrants it, the pope does have a non-regular power to interfere with the 'liberties and temporal rights' of rulers, laymen, and clerics alike, which belong to them by natural law, the law of

144 Brev. 2.16.6-19 (4:142-143): 'videtur michi dicendum quod a regulari et ordinaria potestate concessa vel promissa beato Petro et cuicumque successorum eius per illia verba Christi excipienda sunt iura legitima imperatorum, regum et ceterorum fidelium et infidelium, quae minime obviant bonis moribus, honori Dei et obervationi evangelicae legis, prout in aliis quam in illis verbis Christi: Quodcumque ligaveris etc. a Christo, Evangelistis et Apostolis est plenius tradita et clarius explanata, quae scilicet iura ante institutionem explicitam legis evangelicae habuerunt et uti licite potuerunt: ut huiusmodi iura regulariter et ordinarie absque causa et sine culpa papa de quamcumque potestate sibi data a Christo immediate turbare vel minuere non valeat quoquomodo. Et si de facto aliquid contra ipsa attemptaverit, ipso facto et iure illud, quod facit, nullum est; et si sententiam ferret in tali casu, ipsa tamquam a non suo iudice lata nulla esset ipso iure divino, quod omni iure canonico et civili praeeminere dignoscitur'. The phrase a' non suo iure' is a fairly common phrase in the Decretum and Decretales, and invariably denotes a decision made by someone without the appropriate jurisdiction. See, e.g., C.2 q. 1 c. $7 \S 9 ;$ X 1.4.3; X 1.30.5; X 2.1.4; X 5.38 .4 and cf. C. 3 q. 8 c. 1 ; C.11 q.1 c.49.

145 AP 5.23-25 (1:243); cf. 1 Dial. 7.67 (160ra).

146 3.2 Dial. 1.23 (242ra-rb); cf. 3.2 Dial. 1.23 (242va).

147 3.1 Dial. 1.6.29-35 (8:156). 
nations, or civil law. When the situation is dire enough — ' in casu summae utilitatis vel vicinae aut extremae necessitatis vel propinquae' - it is reasonable that papal 'potestas' be extended so that the community of the faithful not be exposed to the dangers that might arise from the ignorance, idleness, impotence, cowardice, lust, or malice of others. ${ }^{148}$ The ensuing argument was predicated on an assumption of evangelical liberty, another cornerstone of Ockham's political philosophy, and a powerful motivating belief in medieval social and political thought, ${ }^{149}$ which meant for Ockham that the pope did not have the 'potestas' to despoil others of their 'liberties, rights, and things', nor indeed any other 'potestas' by which he could endanger the faithful. ${ }^{150}$ The pope, in short, lacks the power to impose new

148 AP 5.50-64 (1:244): 'Quemadmodum igitur a praedicta generalitate, qua dicitur: Quodcunque ligaveris, etc. excipi debent illa, secundum omnes catholicas sententias, quae sunt contra legem divinam et ius naturae, ita etiam excipi debent illa, quae essent in notabile et enorme detrimentum et dispendium libertatum et iurium temporalium imperatorum, regum, principum et aliorum laicorum et etiam clericorum, quae eis iure naturali, gentium vel civili ante vel post institutionem legis evangelicae competebant. Ad illa enim potestas papalis regulariter minime se extendit, cum absque causa et sine culpa iura turbare non debeat aliorum, Extra, de iudiciis, Novit [X 2.1.13]. Ad quae tamen casualiter, puta in casu summae utilitatis vel vicinae aut extremae necessitatis vel propinquae, rationabile sit ut se possit extendere, quatenus communitati fidelium in omnibus necessariis per Christum provisum erat, ne extremo exponatur periculo propter ignorantiam, ignaviam, impotentiam, pusillanimitatem, quamcunque libidinem vel malitiam quorumcunque'.

149 Shogimen, Ockham and Political Discourse 170-175; Tierney, Idea of Natural Rights 187.

150 AP 5.64-75 (1:244): 'Non enim Christus voluit omnes homines servituti summi pontificis subiugare nec vult ipsum praeesse aliis propter propriam, sed propter communem utilitatem. Et ideo non habet pontifex summus a Christo potestatem pro suae arbitrio voluntatis spoliandi alios libertatibus, iuribus et rebus; nec aliquam potestatem, ex qua leviter possent [read: posset] periclitari fideles temporaliter vel spiritualiter, concessit Christus summo pontifici, sed ut prodesset ipsum praetulit universis, nullam ei tribuens potestatem, per quam ad placitum [posset turbare] aliorum iura, quae ante promulgationem evangelicae legis in se vel in suis parentibus aut praedecssoribus habuerunt, vel etiam post tali iure et modo legitimo adepti fuerunt, quali antea priores acquirere potuerunt'. 
burdens upon Christians where there is no fault to remedy or cause to do so. ${ }^{151}$ After all, as Ockham noted at the start of a long rebuttal of the arguments adduced in Octo quaestiones 1.2, one reason Matthew 16:19 should not be understood to mean an unrestricted fullness of power was that, besides being dangerous for the pope himself, it would also be dangerous for his subjects, among which there were many spiritually weak individuals who would not be able to endure (sufferre) the burdens the pope would be able to impose upon them 'de iure' without justification (absque culpa sua et sine causa). ${ }^{152}$ Ockham's position was of course that the pope did not have such a fullness of power, only 'all power necessary for the government of the faithful in terms of acquiring eternal life, with all reasonable, honest or even licit rights and liberties preserved'. ${ }^{153}$ Ockham then explained: ${ }^{154}$

They say, moreover, 'with the iura and liberties' etc. 'preserved' in order to note that, as long as they are unwilling, the pope can remove the iura or liberties of emperors, kings, or any others, clerics or laymen, by no potestas given to him by Christ, without fault or cause, beyond the case of necessity and utility (which can be made the equivalent of necessity), ${ }^{155}$ provided only that such liberties and iura are not against divine lex (to which all Christians were bound).

The guiding principle for Ockham would seem to be that the pope was entrusted with such power as he has to work for the benefit of

151 Brev. 2.5.104-107 (4:119-20): 'Propter quod non expedit communitati fidelium, ut papa habeat potestatem gravia imponendi fidelibus sine culpa eorum et absque causa manifesta, ad quae nec per ius divinum nec per ius naturale nec per propriam obligationem spontaneam constringuntur'.

${ }^{152} O Q 1.7 .5-16(1: 34)$.

${ }^{153} O Q 1.7 .33-35(1: 35)$.

${ }^{154} O Q$ 1.7.52-63 (1:35): 'Dicunt autem 'salvis iuribus et libertatibus', ad notandum quod papa per nullam potestatem sibi datam a Christo potest tollere iura et libertates imperatorum, regum et aliorum quorumcunque, clericorum vel laicorum, ipsis invitis, sine culpa et absque causa, extra casum necessitatis et utilitatis, quae valeat parificari necessitati, dummodo libertates et iura huiusmodi non sint contra legem divinam, ad quam Christiani tenentur'.

155 Ockham often pointed out that 'utilitas' could (or ought to) be considered equivalent to necessity; see $O Q$ 1.7.56-57 (1:35), 2.8.10-11 (1:82), 3.4.46-47 (1:104); 3.12.115-116 (1:116), 8.6.49-50 (1:200); Brev. 3.8.13-14 (4:181); and IPP 5.12-13 (4:289), 10.12-13 (4:301). In 3.1 Dial. 2.20.141-143 (8:208) the Magister links the idea to X 1.14.6 (2:127). 
the entire community of believers, rather than for his own benefit. In one of his last works (1346/47), he argued that papal rule was ministrative rather than dominative in part because 'it is agreed that the pope . . . cannot take away the liberties and things of his subjects according to the aforesaid "without fault and without reasonable cause" and manifest laws (iura)'.156

Ockham also used 'sine culpa et sine causa' as a way of ordering the hierarchical relationship between papacy and the political authority of secular rulers. As before, this question turns on understanding the limits of papal fullness of power. And, as before, 'sine culpa et sine causa' is treated as a generally evident rule that demonstrates why the pope cannot be said to have a fullness of power with respect to the political authority of secular rulers.

There are five places where Ockham applies this principle to demonstrate the independent legitimacy of secular rule; four of them are largely negative in nature. Twice in An princeps, Ockham wrote that a papal fullness of power would mean that the pope would be able to strip kings of their kingdoms without their fault or without good cause and hand them over to commoners. ${ }^{157} \mathrm{~A}$

${ }^{156}$ IPP 6.11-18 (4:291): 'Cum igitur constet quod papa, cui dixit Christus in beato Petro: Pasce oves meas [Io. 21:17], de fidelibus sollicitam curam gerere teneatur, et iuxta praedicta sine culpa et absque causa rationabili et manifesta iura, libertates et res sibi subiectorum auferre non valeat, [nisi] inquantum valeat $a b$ eis suas necessitates exigere: relinquitur quod principatus papalis institutus est propter utilitatem subiectorum et non propter utilitatem propriam vel honorem, et per consequens non dominativus, sed ministrativus est digne vocandus'. Cf. IPP 7.24-30 (4:293), and 8.1-7 (4:298-99), which both repeat the same basic point.

157 AP 2.84-92 (1:232): 'Posset ergo papa, si haberet talem plenitudiem potestatis, sine culpa et absque causa reges et principes ac alios clericos et laicos universos de dignitatibus suis deponere ipsosque privare omnibus rebus suis et iuribus, ac etiam reges potestati rusticorum et vilium personarum subicere ac ipsos constituere aratores agrorum, et quibuscunque vilibus operibus et artibus deputare; quae absurdissima sunt et libertati evangelicae legis, quae ex divinis scripturis habetur, derogantia manifeste. Quare non solum est falsum papam habere huiusmodi plenitudinem potestatis, sed etiam est haereticum, perniciosum et periculosum mortalibus universis'. And AP 5.20-21 (1:243): 'Tertia est quod papa, sicut deductum est prius, posset de plenitudine 
similar point is made in the Dialogus, though the fullness of power is there connected with 'a most complete lordship of temporal things' (plenissimum dominium). ${ }^{158}$ The Breviloquium, by contrast, connects the stripping of rulers of their realms - in this case, the king of France is singled out in particular - much like lords do with their servants' goods, with the imposing of further religious obligations. Ockham once more invoked the idea that the advent of Christ inaugerated a new evangelical 'law of liberty'. ${ }^{159}$

In the Octo quaestiones a similar point is made, but at much greater length. The argument is attributed to an unspecified 'some people', but it fits in its general dimensions with the other arguments we have considered thus far. ${ }^{160}$ The argument, which is attributed to people who have a less full idea of what papal plenitudo potestatis entails, runs as follows. We can say that imperium is from the pope even though he cannot command supererogatory acts nor deprive people without fault unless there is an underlying cause. ${ }^{161}$ Thus it is that the pope is also unable to

potestatis absque culpa et sine causa privare reges regnis suis et dare ea rusticis quibuscunque obedire'.

${ }^{158}$ 3.1 Dial. 1.12.15-22 (8:150): 'Si igitur papa haberet super omnes Christianos talem plenitudinem potestatis, papa haberet plenissimum dominium in temporalibus super omnes reges et principes ac alios universos, et omnes essent servi eius, et posset de plenitudine potestatis, sine omni culpa et absque omni causa, privare quemcumque regem regno et dare illud cuicumque pagano; posset regem subicere cuicumque rustico ad sue arbitrium voluntatis, et, si faceret, de facto teneret, nec posset rex quicumque in talibus vel consimilibus sibi licite resistere - quod isti falsum reputant et absurdum'.

${ }^{159}$ Brev. 2.3.51-54 (4:115): 'Posset ergo papa de iure privare regem Franciae et omnem alium sine culpa et absque causa regno suo, quemadmodum dominus absque causa et sine culpa potest tollere a servo suo rem, quam sibi concessit: quod est absurdum. Posset etiam papa, si talem haberet tam in temporalibus quam in spiritualibus plenitudinem potestatis, multo plures et graviores caerimonias imponere Christianis quam fuerint caerimoniae veteris legis; quare nullo modo lex evangelica esset lex libertatis, sed intolerabilis servitutis'. Cf. IPP 5.42-47 (4:290).

${ }^{160}$ Cf. $O Q 2.10 .14-33$ (1:86-87); IPP 5.8-19 (4:289).

${ }^{161}$ Offler identified the phrase 'sine culpa nisi subsit causa' as from VI 5.13. reg. 23 in the places marked in the text of the next footnote (see n. 65 for the text). This is plausible insofar as he quoted other specific regulae explicitly in the Octo quaestiones. However, the phrase is also used directly in the gloss Sine 
deprive individuals who justly possess kingdoms and other political domains (principatus) without fault, again except where there is an underlying cause. But when the cause is great enough, depriving an emperor of an empire can be done; similarly, he might even insist that no one be elected to a kingdom or empire if it is necessary for the common good. ${ }^{162}$ Ockham tied, in other words, 'sine culpa et sine causa' to other powerful maxims of medieval political thought, namely that concern for the common

sua (see n. 71, above), and it is perhaps significant that he never directly referred to this regula elsewhere; cf., e.g., n. 165 , below.

$162 O Q$ 2.2.13-43 (1:70-71): 'Alii autem, quamvis putent opinionem praedicta[m] sapere haeresim manifestam, tamen dicunt imperium esse a papa propter hoc, quod secundum eos papa habet quandam aliam plenitudinem potestatis; quia, licet, ut dicunt, papa non possit omnia sine exceptione, quae non sunt prohibita neque per ius divinum neque per ius naturale, quia illa, quae supererogationis sunt, non potest praecipere, nec potest aliquem privare iure suo sine culpa, nisi subsit causa [VI 5.13. reg. 23], nec potest illa, quae ad regendum mortales minime necessaria dignoscuntur, licet valeant expedire: tamen per seipsum vel institutos officiales ab ipso omnia sine exceptione potest, quae constat esse necessaria regimini subiectorum. Unde licet reges et principes iam iuste regna et principatus habentes absque culpa, nisi subsit causa, nequaquam possit regnis suis et principatibus privare etiam de plenitudine potestatis suae, tamen si esset aliquis populus, qui regem, principem aut caput in temporalibus non haberet, cum non solum expediens sed etiam necessarium sit cuilibet populo etiam in temporalibus caput, a quo immediate regatur, habere, posset papa de plenitudine potestatis absque electione, nominatione vel consensu eorum ipsis caput praeficere, maiorem vel minorem dignitatem et potestatem tribuendo eidem; et in similibus circa potestatem eius similiter est dicendum. Et ex ista plenitudine potestatis, ut dicit ista opinio, habet papa potestatem super imperatorem et imperium, non quidem ut possit imperatorem sine culpa, nisi subsit [VI 5.13. reg. 23] causa necessaria privare imperio, nec quod possit ad libitum suum imperium transferre de gente in gentem, sed quia pro culpa et ex causa necessaria potest imperatorem, quibuscunque aliis minime requisitis, deponere, si hoc sit necessarium utilitati communi, et non solum expediens, potest de plenitudine potestatis, non requisitis aliis quibuscunque, de gente in gentem vel de domo in domum aut de persona in personam transferre imperium; si etiam ex causa aliqua evidenti necessarium fuerit bono communi, ut nullus ad regnum vel imperium eligatur, potest ordinare, et praecipere ut nullus ad regnum vel imperium eligatur, potest ordinare et praecipere ut, quamdiu necessarium fuerit, huiusmodi electio differatur'. 
good and the demands of necessity take precedence over the rights of any one individual, even one so important as the emperor. ${ }^{163}$

Ockham's interest in describing the proper scope of authority of the papacy far exceeded a similar concern for that of the imperial office, but 'sine culpa et sine causa' nonetheless played a role in this latter case as well. According to the principle that a government is better to the degree it rules for the common good, ${ }^{164}$ Ockham thought it clear that an independent king or emperor in the greatest of realms would not be able to deprive his subjects of 'their goods, liberties, or rights without their fault, unless manifest cause should be present'. Significantly, what people acquire for themselves, are not (also) acquired for their ruler; that is, what is acquired remains free from his arbitrary control. $^{165}$

\section{Conlusions}

The 'sine culpa et sine causa' principle had a variable history in the middle ages. If the maxim itself seems unexceptionable - after all, taking away rights for reasons other than fault or cause seems to be the height of injustice - it was one mechanism by which jurists could meet the expectations of justice

163 Cf. the general comments in Antony Black, 'The Individual and Society', The Cambridge History of Medieval Political Thought, c. 350-c.1450, J. H. Burns ed. (Cambridge 2005 [1988]) 595-597. See also the provocative Janet Coleman, 'Are There Any Individual Rights or Only Duties?' Transformations in Medieval and Early-Modern Rights Discourse, eds., V. Mäkinen and P. Korkman (The new synthese historical library, 59; Dordrecht 2006) 3-36. Shogimen, Ockham and Political Discourse 250-256, related Ockham's concern for the common good to his ethical and epistemological commitments (primarily as expressed in his political writings). ${ }^{164} O Q$ 8.5.36-42 (1:197-98).

$165 O Q$ 8.5.42-46 (1:198): 'Unde imperator vel rex optimo praeeminens principatu, qui sit omni alii principatui impermixtus, habet subiectos tam liberos, ut ipsos de iure absque culpa eorum, nisi causa subfuerit manifesta, non possit privare rebus, libertatibus suis vel iuribus: nec quicquid acquirunt regi vel imperatori acquirunt, ut pro libitu suo de iure possit taliter acquisitum sibi accipere et retinere vel dare cui sibi placuerit: quae tamen et alia multa potest dominus super eos, qui sibi sunt conditione servili subiecti’ 
even as they knew positive rights could not be absolute. ${ }^{166}$ As is so often the case in legal history, the importance lies not in the maxim itself, but the context and way in which it was applied. This is clear with Innocent, who seems not to have relied on 'sine culpa et sine causa' as an explicit principle that should guide his interpretation of the Decretales. Yet, this does not mean that the pope was not a defender of individual rights. Far from it: Innocent is well known for his support of the idea that non-Christians normally held lands and properties (dominia et iurisdictiones) legitimately. ${ }^{167}$ In that same commentary, Innocent went on to give reasons why non-Christians might be punished, which usually involved acting against the 'lex' of nature, deduced by Innocent in this case from the Bible. ${ }^{168}$ And in one telling passage, he even suggested that the Pope 'could, if they treated Christians badly, deprive them by [judicial] sentence of the jurisdiction and lordship, which they hold over those Christians'. Even so, he added 'the 'causa' ought to be great'. ${ }^{169}$

Hostiensis did not quite share Innocent's opinion regarding non-Christian domains. ${ }^{170}$ In some ways this is surprising since he seems to be a more vocal proponent of the sanctity of individual rights, and certainly a stronger proponent of 'sine culpa et sine causa'. In other ways it may not be, for it is by no means clear that medieval jurists applied their principles consistently outside Christendom. Regardless, Hostiensis was more inclined to the idea that prosecuting one's right does not normally cause harm, though of course he clearly did not believe that one has a 'right to do wrong' or anything of the sort. Avoiding scandal takes precedence over exercising one's right. Hostiensis, like the texts of the Gloss, privileged cause over fault as the chief reason for taking away

\footnotetext{
${ }^{166}$ Helmholz, 'Natural Human Rights' 304.

${ }^{167}$ Innocent IV to X 3.34.8, n. 3, v. 'compensato' (430ra). J. Muldoon, 'Extra ecclesiam non est imperium: The Canonists and the Legitimacy of Secular Power', Studia Gratiana 9 (1966), 553-580, is a classic analysis of this topic. ${ }^{168}$ Innocent IV, Commentaria to X 3.34.8, fol. 430rb s.v. compensato.

${ }^{169}$ Ibid. fol. 430va.

${ }^{170}$ Federick H. Russell, The Just War in the Middle Ages (Cambridge Studies in Medieval Life \& Thought, Third Series 8; Cambridge 1975) 200-201.
} 
one's rights. As fault pertains to the individual, while cause is an external reason, what Hostiensis (and the Gloss) were in fact privileging was the idea that a competent authority with the requisite iurisdictio had the power to decide when there were legitimate grounds for interfering with another person's rights. This seems consistent with another powerful legal principle, namely the special exemption to the law (lex) that necessity can provide - a point Hostiensis also defended. ${ }^{171}$ In a related manner Hostiensis wrote that 'a just and necessary cause should be exempt from every "ius". , 172 If rights are not absolute, thought Hostiensis, neither is (positive) law (ius).

Ockham's reading of the canonistic texts was much different. ${ }^{173}$ It is clear that he was uninfluenced by the leading decretalists of the thirteenth century; and the same must be said, on this score at least, of Guido de Baysio, who is sometimes thought to have been one of Ockham's entry points into canonistic thought. I have not discussed him above because the Archdeacon simply did not have much of interest to say about 'sine culpa et sine causa' in the passages that Ockham relied on. There is, for instance, no mention of the principle in his comments to either D. 22 c. 6 or D.56 c.7, although his commentary to the former passage demonstrates that Guido was aware of some of the (by

${ }^{171}$ E.g., Hostiensis, Lectura to X 1.6.42, fol. 67r.

${ }^{172}$ Hostiensis, Lectura to X 3.12.1, fol. 56vb s.v. necessaria: 'Nota quod ab omni iure semper iustam causam et necessariam intelligi debere exceptam, et de hoc notatur supra titulo i. c. finali [X 3.1.16] et de his quae fiunt a prelat. Nouit et c. finali [X 3.10.4 and 10] et supra, de concessione praebende, Cum nostris § finali [X 3.8.6] et infra de accusationibus, Cum dilecti [X 5.1.18], infra de uerborum significatione, Intelligentia [X 5.40.6], xxix. di. c.i. [D.29 c.1], infra, de sponsalibus, Ex literis Siluani ad finem [X 4.1.10], supra de clericis non residentibus, Inter quatuor [X 3.4.10], ubi de hoc. Set que potest hec esse causa? Guerra, litigium, magna emptio, longa peregrinatio, et quaelibet iusta paupertas. Argumentum, infra de donationibus, Ad apostolice [X 3.24.9], infra de religiosis domibus c.ii. [X 3.36.2], xvi. q.i. Et temporis qualitas [C.16 q.1 c.48]; infra, de censibus, Cum apostolus [X 3.39.6] ubi de hoc'. It is significant that the examples Hostiensis chose pertained to ecclesiastical matters.

${ }^{173}$ Cf. Pennington, 'Lex naturalis' 243-244 who recently analyzed Aquinas's reading of Gratian. 
then) standard 'causae'. ${ }^{174}$ There is an acknowledgement that 'iura' are to be preserved at Inuentum est (C. 16 q. 7 c. 38), but this would not have been enough for Ockham to make the references to the Glossa ordinaria that he did. ${ }^{175}$ Moreover, as far as I can tell, Ockham never referred to this canon in his own writings.

In any event, Ockham's reading of the import of the glosses differed markedly from the earlier canonists. His application has its own mix of strengths and weaknesses. The downside of his analysis is that Ockham seems to have ignored the glosses' casuistry in favor of treating 'sine culpa et sine causa' as if it were meant only to limit the power of individuals rather than being a principle that allowed one to analyze whether there was any reason to limit or take away someone's rights. This came at the cost of turning 'sine culpa et sine causa' into something of a blunt instrument, the main value of which was, first, to defend individual rights, liberties, and possessions against arbitrary seizure; and, second, to demarcate the proper, and properly limited spheres of political influence for secular and especially ecclesiastical rulers. In Ockham's hands the maxim was used primarily to end arguments about the reach of political authority rather than being used as the starting point for an analysis of where specific rights in specific situations should prevail or give way to the rights and duties of others. While there is good reason to applaud his effort to curb arguments for absolutistic political authority, it is worth pausing to consider that, at the most fundamental level, the only valid cause Ockham invoked is the necessity of the common good. And yet necessity did not need any further support to justify extraordinary interventionism. It was not just Hostiensis, but medieval theologians and jurists alike who

174 See Guido de Baisio, Rosarium super Decreto, mit Brief an Petrus Albignanus von Paulus Pisanus und dessen Erwiderung, Juni 1480 (Venice 1480), http://daten.digitale-sammlungen.de/ db/0004/bsb00048042/image_1, to D. 22 c. 6 (unfol.), which discussed the text in terms of privileges.

175 Rosarium to C.16 q.7 c.38 (unfol.): 'Episcopi autem et alii debent iura seruare, extra de accusationibus, Ad petitionem in fine [X 5.1.22] et sic non contradicet, extra de statu monachorum [X 3.35.2]. Guillelmus Naso’. 
appealed to the idea that necessity is not subject to the law. ${ }^{176}$

Still, perhaps it is a little unfair to expect of Ockham the same degree of analysis of 'sine culpa et sine causa' as the canonists provide us. His goals after all were much different. Moreover, if the value of a legal maxim lies in its application rather than its (usually) self-evident nature, then there is nothing wrong prima facie with Ockham applying it to a sphere rather far removed from the concerns of juristic commentaries. The jurists remain among the most important sources for medieval political thought, but they were not political philosophers or theorists as we understand the term today. ${ }^{177}$ Thus, unlike Ockham, when Innocent IV and Hostiensis had occasion to write about the supposed sanctity or inviolability of individual rights, they were usually concerned with why someone's right had in fact been limited or taken away. In such cases, 'sine culpa et sine causa' could be invoked only to explain the loss of right, and it is usually understood as the exception that proves the rule.

Ockham came much closer to theoretical system-building, though he was motivated primarily by the burning concern that, since the time of John XXII, the leadership of the Church had fallen into heresy. This concern with heresy led to a reconsideration of the nature of and normal limits to political authority, especially for the pope, but also for emperors and even non-Christian rulers. And it was the limits that most interested Ockham. This is where 'sine culpa et sine causa' was to play so great a role in his political worldview. It is of course true that medieval conceptions of government were not absolutistic. Popes knew they should not normally interfere with the rights and prerogatives of lay rulers without their consent. ${ }^{178}$ And when Bulgarus famously (so one story goes) lost a horse for denying that

176 See, above all, Franck Roumy, 'L'origine et la diffusion de l'adage canonique Necessitas non habet legem (VIII ${ }^{\mathrm{e}} \mathrm{XIII}{ }^{\mathrm{e}} \mathrm{s}$.)', Medieval Church Law and the Origins of the Western Legal Tradition: A Tribute to Kenneth Pennington, W. P. Müller, M. E. Sommar edd. (Washinton, DC 2006) 301-319. ${ }^{177}$ Cf. Tierney, 'Ockham, the Conciliar Theory' 65; and C. Morris, The Papal Monarchy: The Western Church from 1050 to 1250 (Oxford History of the Christian Church; Oxford 1989) 568-569.

178 Tierney, 'Continuity of Papal Political Theory' 243. 
the emperor was 'dominus mundi' 'with respect to ownership' (quantum ad proprietatem), ${ }^{179}$ we might reasonably wonder if Frederick Barbarossa himself wondered if the law books taught that he could expropriate or otherwise dispose of his subjects' property without their consent. ${ }^{180}$ Bulgarus was not alone in his answer, but his appeal to equity — 'dixi equum' — operated at a different level than Ockham, even though he too denied the emperor (and pope) similar powers: ${ }^{181}$

Hence, neither the pope nor the emperor ought to have such a power over the community of the faithful, because none of them is able to remove the rights and liberties of their inferiors without fault and without cause - except in a case of necessity.

Surely it is a belief in the principle of equity that underwrites Ockham's repeated application of 'sine culpa et sine causa', here and elsewhere, yet he left the connection unstated. One might be inclined to believe he thought 'sine culpa et sine causa' was merely a self-evident principle, unconnected to deeper considerations.

But it is not just 'because it is wrong' that Ockham utilized - and, indeed, universalized — 'sine culpa et sine causa'. Ockham of course cared very deeply about the ethics of right and wrong, but the reason for the strong emphasis on this principle is connected to another deeply held belief of his, namely a belief in the importance of, and indeed promise of, individual freedom through the new evangelical law of liberty. The starting point of 'sine culpa et sine causa' may have been due to his discovery of this canonistic idea, and in his belief in how private property first arose — and it is significant that he loosely referred

179 F. Güterbock, ed., Das Geschichtswerk des Otto Morena und seiner Fortsetzer über die Taten Friedrichs I. in der Lombardei (Scriptores rerum Germanicarum, Nova series, 7; Berlin 1930) 59.

${ }^{180}$ Kenneth Pennington, The Prince and the Law, 1200-1600: Sovereignty and Rights in the Western Legal Tradition (Berkeley 1993) 8-37, analyzed the story and considered its fate at the hands of subsequent jurists.

$181 O Q$ 1.11.16-18 (1:45): 'Unde talem potestatem nec papa nec imperator habere debet super communitatem fidelium, quia nullus eorum valet tollere iura et libertates inferiorum sine culpa et absque causa, nisi in casu necessitatis'. 
to 'sine culpa et sine causa' when he argued against John that Adam would not have lost his 'dominium proprium' without any fault of his own simply because Eve was brought into being ${ }^{182}$ but it quickly became integrated into a larger defence of humankind's freedom to acquire property and create governments in our fallen state. As Tierney has most recently emphasized, these activities occur within the framework of a (belief in a) permissive natural law. In our post-lapsarian world, it is expedient and useful, and indeed even necessary for living well. But it is not, strictly speaking, necessary that there be private property; ${ }^{183}$ nor is it necessary that governments and various regimes of private or communal ownership be such as they now happen to be.

It is his strong emphasis on our freedom, Christian and non-Christian alike, to arrange many aspects of our affairs that made one commentator label Ockham a defender of "human freedom." " 84 Ockham was not unique in this regard, for medieval canonists were no less able defenders as well. Like Ockham, they operated on the assumption that people were 'capable of deliberating and of choosing to the good and to avoid the evil' ${ }^{185}$ Rufinus's well-worn description of ius naturale as 'a certain force implanted in human being(s) by nature for doing good and avoiding its opposite' is by no means out of place here. ${ }^{186}$ It is a power, individually 'had', which we might — lamentably -

182 OND 27.85-96 (2:488). Ockham did not believe Adam had exclusive lordship prior to the Fall; he was simply giving another reason why the pope's belief that Adam had had such lordship was incoherent.

183 Brev. 3.7.47-77 (4:179-180); see Tierney, Liberty and Law 100-116.

${ }^{184}$ Shogimen, Ockham and Political Discourse 232-262.

185 Reid, 'Thirteenth-Century Canon Law and Rights' 330-331, 340-341. Or, to approach the matter from a different perspective, consider the rich medieval jurisprudence devoted to the problem of proving insanity: what seemed much less debatable was that wrongful actions could be imputed to a furiosus; e.g., Dig. 47.10.3.1 (1:830). As Gratian noted once, insanity is punishment enough: 'cum non sit peccatum, est tamen pena peccati', C.15 q.1 d.p.c. 2 1 (1:746). Regarding the burden of proof, see Brandon T. Parlopiano, 'The Burden of Proving Insanity in the Medieval Ius commune', The Jurist 72 (2012) 515-543.

${ }^{186}$ Rufinus, in H. Singer ed., Summa decretorum magistri Rufini (Paderborn 1963 [1902]), to D.1 d.a.c.1 (6). 
misuse, but that is not its purpose. It is tied to an objective moral order.

Ockham has lately been described as 'liberal or constitutionalist' for his belief that the natural rights and liberties of individuals put constraints on rulers; ${ }^{187}$ this same stress on inalienable rights and liberties has led others to consider Ockham a proponent of a form of republicanism. ${ }^{188}$ What is good about both these analyses is that they recognize the rights and liberties as existing within a larger commitment to the ideal of government existing and working for the common good. Thus, a concern for rights and liberties, which rulers were to allot and preserve alongside necessary and just laws, ${ }^{189}$ might well need curtailing or revoking in the name of the common good, necessity, or utility. ${ }^{190}$ As Hostiensis once explained: 'public utility is preferred to private utility . . . a greater good is to be preferred to a lesser . . . [and] common utility is to be preferred to private utility'. ${ }^{191}$ Similarly, while canonists all agreed that most 'iura' could be renounced, ${ }^{192}$ for his part, Innocent pointed out that a 'ius publicum' could not. ${ }^{193}$ At another point in his commentary, he noted that things introduced for public utility were also not renounceable. ${ }^{194}$ Utility and the common good often trump an individual's 'ius'. Or, as Ockham would often later say, utility can be made equal or

187 Tierney, Idea of Natural Rights 183.

188 Shogimen, Ockham and Political Discourse 256-261.

${ }^{189}$ Cf. $O Q$ 3.8.4-7 (1:109-110): ‘ . . . ad principantem, de quo est sermo, multa pertineant, videlicet iura sua unicuique tribuere et servare, leges condere necessarias atque iustas, iudices inferiores et alios officiales constituere . . . .

190 Such a concern is often evident in Ockham's writings; many are noted by Tierney, Idea of Natural Rights 189-191.

191 Hostiensis, Lectura to X 1.9.10, fol. 94vb, 95ra, 97ra): 'Nam publica utilitas prefertur priuate . . . ; quia maius bonum minori est preferendum . . . ; Sic ergo habes hic argumentum quod communis utilitas preferenda est priuate ...' Cf. Dig. 1.1.11, one of the stronger classical statements to connect 'ius' and the interests of a people.

${ }^{192}$ X 2.2.12.

${ }^{193}$ Innocent IV to X 2.2.12, fol. 198rb, n.1; Innocent IV to X 2.26.16, fol. 300vb, n.1.

${ }^{194}$ Innocent IV to X 1.29.43, fol. $144 \mathrm{rb}, \mathrm{n} .1$. 
compared to necessity. ${ }^{195}$

However, Shogimen's insistence on inalienable rights and Tierney's on natural ones distort the picture: most rights, then and now, are 'temporal', that is, the products of human positive law. Some rights and liberties Ockham imagined surely were natural, and therefore inalienable; but many were not. ${ }^{196}$ I would argue that Ockham thought most were not. That is, it is not because they were natural or God-given that rendered them exempt from arbitrary despoliation. To take the example of property, it is surely incorrect to imagine that Ockham was more worried about a ruler taking away an individual's 'right' to acquire property than arbitrary interference with one's actual property. But only the former is (normally) God-given: it is, in Miethke's words, a 'potestas acquirendi dominium', which one may (or may not) choose to exercise. ${ }^{197}$ Actual property ownership is historically contingent, based in human law, and fundamentally (according to the Franciscan perspective, at least) alienable and renounceable. In fact, many rights and liberties can be voluntarily restricted, 'by vow, promise, or some such other way', by their possessor; and this too is due to the promise of the law of evangelical liberty. ${ }^{198}$

195 Cf. Gaines Post, 'Theory of Public Law', Seminar 6 (1948) 51-55. For Ockham, see n. 155, above.

196 Ockham could have been more helpful here. Sometimes the rights and liberties are described as given by God (and nature), sometimes there is no further specification. The Breviloquium is a good illustration of the problem. Brev. prol. 6-11 (4:97), 2.17.3-6 (4:146), and 2.20.18-28 (4:154), clearly speak of the former; whereas Brev. 2.21.30-33 (4:156), is uncertain; and Brev. 4.1.40-46 (4:194-195) and 5.1.11-14 (4:221) seem clear descriptions of human law-based rights and liberties. Cf. AP 6.148-181 (1:250-51).

197 Jürgen Miethke, 'Dominium, ius und lex in der politischen Theorie Wilhelms von Ockham', Lex und Ius: Beiträge zur Grundlegung des Rechts in der Philosophie des Mittelalters und der Frühen Neuzeit, eds. A. Fidora, M. LutzBachmann, A. Wagner (Politische Philosophie und Rechtstheorie des Mittelalters und der Neuzeit, Texte und Untersuchungen, II.1; Stuttgart-Bad Cannstatt 2010) 250-51; cf. J. Miethke, 'The Power of Rulers and Violent Resistance Against an Unlawful Rule in the Political Theory of William of Ockham', Revista de ciencia política 24.1 (2004) 214.

${ }^{198}$ IPP 9.26-34 (4:300-301): 'Ut autem generaliter explicetur, quae spectant ad iura et libertates aliorum laicorum et clericorum, religiosorum et saecularium, puto quod huiusmodi sunt omnia illa, quae nec bonis moribus, nec hiis, quae in 
But despite their mundane origins and justification, they are no less inviolable outside cases of necessity or where no fault or cause attaches for their restriction or removal. Any government which could interfere with any non-natural rights without fault or cause was unlikely to be one aiming for the common good - neither for Ockham, nor for the canonists, nor for many others besides.

The Catholic University of America.

Novo Testamento docentur, inveniuntur adversa, ut ab huiusmodi nullus Christianus sine culpa et absque causa rationabili et manifesta per papam valeat coerceri, nisi ad abstinendum ab aliquo tali per votum promissionem vel alium quemvis modum sponte obligaverit semetipsum, vel per alium superiorem suum, cui debeat obedire, astringatur. Et haec est libertas evangelicae legis, quae in sacris litteris commendatur'. 